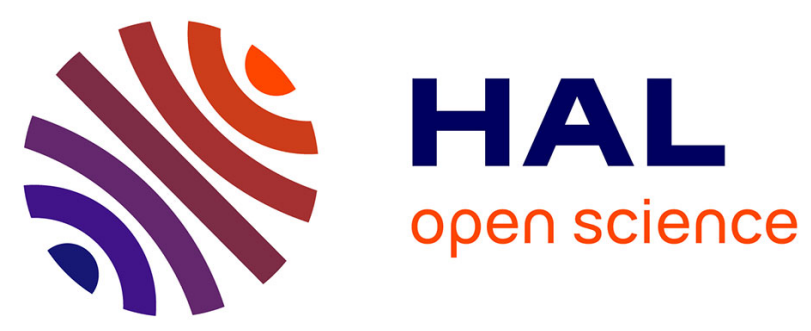

\title{
Late Pleistocene slip rate of the central Haiyuan fault constrained from OSL, 14C, and cosmogenic isotope dating and high-resolution topography
}

Yanxiu Shao, Jing Liu-Zeng, Jérôme van Der Woerd, Yann Klinger, Michael Oskin, Jinyu Zhang, Peng Wang, Pengtao Wang, Wei Wang, Wenqian Yao

\section{To cite this version:}

Yanxiu Shao, Jing Liu-Zeng, Jérôme van Der Woerd, Yann Klinger, Michael Oskin, et al.. Late Pleistocene slip rate of the central Haiyuan fault constrained from OSL, 14C, and cosmogenic isotope dating and high-resolution topography. Geological Society of America Bulletin, 2020, 10.1130/B35571.1 . hal-03012211

\section{HAL Id: hal-03012211 \\ https://hal.science/hal-03012211}

Submitted on 27 Nov 2020

HAL is a multi-disciplinary open access archive for the deposit and dissemination of scientific research documents, whether they are published or not. The documents may come from teaching and research institutions in France or abroad, or from public or private research centers.
L'archive ouverte pluridisciplinaire HAL, est destinée au dépôt et à la diffusion de documents scientifiques de niveau recherche, publiés ou non, émanant des établissements d'enseignement et de recherche français ou étrangers, des laboratoires publics ou privés. 


\section{Late Pleistocene slip rate of the central Haiyuan fault}

2 constrained from $\mathrm{OSL},{ }^{14} \mathrm{C}$, and cosmogenic isotope

3 dating and high resolution topography

4

5 Yanxiu Shao ${ }^{1,2,3^{*}}$, Jing Liu-Zeng ${ }^{1}$, Jérôme Van der Woerd ${ }^{4 *}$, Yann Klinger ${ }^{2}$,

6 Michael E. Oskin ${ }^{5}$, Jinyu Zhang ${ }^{6}$, Peng Wang ${ }^{6}$, Pengtao Wang ${ }^{3}$, Wei Wang ${ }^{6}$,

7 Wenqian $\mathbf{Y a o}^{6}$

8

$9{ }^{1}$ Institute of Surface-Earth System Science, Tianjin University, Tianjin 300072, China

10 22Université de Paris, Institut de Physique du Globe de Paris, CNRS, F-75005 Paris,

11 France

$12{ }^{3}$ Lanzhou Institute of Seismology, China Earthquake Administration, Lanzhou,

13730000 China

$14{ }^{4}$ Institut de Physique du Globe de Strasbourg UMR 7516 CNRS Université de

15 Strasbourg, 5 rue René Descartes, 67084 Strasbourg Cedex, France

$16{ }^{5}$ Department of Earth and Planetary Sciences, University of California, Davis,

17 California 95616, USA

$18{ }^{6}$ Institute of Geology, China Earthquake Administration, Beijing, 100029 China

19

20 Y.SHAO: shaoyx@geoidea.org

21 J. Van der Woerd: jerome.vanderwoerd@unistra.fr 


\section{ABSTRACT}

24 To better constrain the long-term millennial slip-rate of the Haiyuan fault in its central 25 part, we revisit the site of Daqing (or Sangedun at $102.7^{\circ} \mathrm{E}$ in Gaudemer et al., 1995).

26 We used terrestrial LiDAR to build a high-resolution DEM and Uncrewed Aerial 27 Vehicle to build an aerial photomosaic with $\sim 0.1 \mathrm{~m}$ resolution to survey the offset 28 terraces, their geomorphology and the fault trace. We refine the geomorphological 29 interpretation of the site, measure terrace riser offsets and determine their relation to 30 terrace formation. The well-constrained age of the highest terrace T3 at $13.7 \pm 1.5 \mathrm{ka}$ 31 determined from the combination of surface and sub-surface OSL, ${ }^{14} \mathrm{C}$, and terrestrial 32 in situ ${ }^{10} \mathrm{Be}$ cosmogenic radionuclide (CRN) dating, associated with an offset of $88 \mathrm{~m}$, 33 yields a late Pleistocene minimum slip-rate of $6.5 \pm 1 \mathrm{~mm} / \mathrm{yr}$. The less well 34 constrained offset $(<72 \pm 3 \mathrm{~m})$ and age $(>9.3 \pm 0.6 \mathrm{ka})$ of terrace T2 yield a maximum 35 slip rate of $7.7 \pm 0.6 \mathrm{~mm} / \mathrm{yr}$. The smallest offset of a gully incised into T1 of $6.0 \pm 0.5$ $36 \mathrm{~m}$ is potentially associated with the most recent slip event that occurred in the last 37 millennia. The Daqing site provides a well constrained slip rate of the Haiyuan fault 38 that is consistent with geodetic estimates. Overall, the high-resolution topography and 39 precise chronology at the same site makes it possible to reveal the geomorphic complexities of terrace riser offsets and post-depositional evolution, and to show how

41 previous geological rates along the fault were both under- and over-estimated.

43 Keywords: Haiyuan fault, northern Tibetan Plateau, slip rate, LiDAR, cosmogenic 44 nuclide dating 


\section{INTRODUCTION}

How strain is distributed in the Tibetan-Himalayan orogen is important to understand how continental orogens deform (Tapponnier and Molnar, 1977; England and Molnar, 1997). The Haiyuan left-lateral strike-slip fault, whose eastern part ruptured in $1920 \mathrm{AD}$ for a length of about $230 \mathrm{~km}$ (Deng et al., 1984), is a major

52 strike slip fault at the northeastern margin of the Tibetan Plateau. This fault plays an important role in accommodating eastward motion of the northern Tibet plateau relative to the Gobi-Alashan to the north (Tapponnier and Molnar, 1977; Gaudemer et al., 1995; Tapponnier et al., 2001a).

Overall, decadal geodetic and millennial geological slip-rate studies mostly agree to a rate of $4-10 \mathrm{~mm} / \mathrm{yr}$, implying that the Haiyuan fault is the major active fault at the rim of Tibet at this longitude (Li et al., 2009; Daout et al., 2016; Jiang et al., 2017). However, higher slip rates have been documented (Zhang et al., 1988a; Gaudemer et al., 1995; Lasserre et al., 1999, 2002), as well as lower ones (Yuan et al., 1998; Li et al., 2009; He et al., 2010; Jiang et al., 2017; Matrau et al., 2019). Because it has been suggested that the fault slip rate might vary over time, thus, it is valuable to find multiple slip-rate constraints at a single site to constrain possible temporal slip-rate variation (e.g., Sieh and Jahns, 1984; Van der Woerd et al., 1998, 2002).

Terrace risers have commonly been used as markers of fault displacement to constrain slip rates along strike slip faults (e.g., Lensen, 1968; Weldon and Sieh, 1985; Berryman, 1990; Knuepfer, 1992; Van der Woerd et al., 1998, 2002; McGill et al., 2013). However, terrace risers can be seldom directly dated. One may infer displacement started to be recorded since the time of upper terrace abandonment, or upon abandonment of the lower terrace (Van der Woerd et al., 2002; Mériaux et al., 2004, 2005; Cowgill, 2007; Zhang et al., 2007). In general, the upper terrace constraints yield a minimum slip rate, while the lower terrace constraint yields a maximum slip rate. Ideally, when terrace ages are not too different, a combination of 
upper and lower age constraints may be used to bracket the riser age (Mériaux et al., 2005; Cowgill, 2007).

The precision of a late Quaternary slip rate depends upon displacement accumulation and its uncertainty, as well as the reliability of the corresponding dating (Sieh, 1981; Weldon and Sieh, 1985; Van der Woerd et al., 1998, 2006; Cowgill, 2007; Zhang et al., 2007; Cowgill et al., 2009; Gold et al., 2009; Le Béon et al., 2012; Mériaux et al., 2012). Across the Qilian Shan-Hexi Corridor, loess covers late Quaternary surface broadly. Researchers have often used optically stimulated luminescence (OSL) or radiocarbon ages of materials collected within the basal loess to date the end of terrace emplacement (e.g. Li et al., 2009; Jiang et al., 2017; Liu et al., 2018). In this area several studies indicate that loess deposition started just prior to the Holocene ( 13-10 ka) (Stokes et al., 2003; Küster et al., 2006). Thus, loess deposition age is a minimum age for the terraces. Because terraces capped by loess usually consist of coarse gravels, if one could correct for the shielding effect due to loess cover, in-situ cosmogenic nuclides should be an appropriate dating method, ideally complemented by OSL and ${ }^{14} \mathrm{C}$ dating of loess capping materials (e.g., Hetzel et al., 2004, 2019; Perrineau et al., 2011).

High-resolution topographic data make it possible to image subtle landforms and deformation features due to active tectonics, and to make reproducible and precise measurements, improving understanding of rupture history and slip along faults (e.g. Hudnut et al., 2002; Oskin et al., 2007; Arrowsmith and Zielke, 2009; Zielke et al., 2010, 2015). Satellite or aerial photography offers two-dimensional imagery which is often used to trace fault line and look for offset markers (e.g., Tapponnier and Molnar, 1977; Peltzer et al., 1989; Meyer et al., 1998; Lasserre et al., 1999; Klinger et al., 2011; Middleton et al., 2016). Studies have applied Airborne Laser Scanning (ALS) data to map fault-zone features (e.g., Hudnut et al., 2002; Oskin et al., 2007; Arrowsmith and Zielke, 2009; Liu-Zeng et al., 2013), to survey coseismic surface ruptures (Oskin et al., 2012; Clark et al., 2017; Langridge et al., 2018) or to determine 
102 paleo-earthquake slip distributions (Zielke et al., 2010, 2012; Thackray et al., 2013;

103 Chen et al., 2015). Recently, this technique has also been used to measure the most

104 recent rupture traces and offsets along the eastern Haiyuan fault (Chen et al., 2014,

105 2018; Ren et al., 2016).

106 Based on new high-resolution topography data and high precision dating, we 107 revisit the Daqing site (also named Sangedun site in the study of Gaudemer et al., 108 1995), a location with multiple marker offsets, to reassess the slip rate of the Haiyuan

109 Fault. We constrain the slip rate at this site with new offset measurements and a 110 combination of absolute age dating approaches.

\section{GEOLOGIC SETTING}

113 The Haiyuan fault extends for $\sim 1000 \mathrm{~km}$ from Hala $\mathrm{Hu}$ within the Qilian Shan in

114 the west to the Liupan Shan in the east (Figure 1) (e.g., Tapponnier and Molnar, 1977;

115 Gaudemer et al., 1995). Thermochronological data indicate that the Haiyuan fault

116 initiated along its western section, then propagated eastward to the Liupan Shan area

117 (Zheng et al., 2006; Duvall et al., 2013). The fault is characterized by left-lateral

118 strike slip with oblique-slip components along some strands (Tapponnier and Molnar,

119 1977; Burchfiel et al., 1989; Gaudemer et al., 1995; Lasserre et al., 1999; Zhang et al.,

120 1988a). Six major 70 to $300 \mathrm{~km}$-long sections are distinguished and delimited by

121 major step-overs or branches (Figure 1). Half-way along the Haiyuan fault, a major

122 branch, the Gulang-Zhongwei fault, splays off the Haiyuan fault at the junction of the

123 Lenglong Ling and Jinqiang He sections. It turns back towards the Haiyuan fault east

124 of $106^{\circ} \mathrm{E}$ in the Liupan Shan section. Large historical earthquakes, such as the 1709

125 AD Zhongwei M7.5, the 1920 AD Haiyuan Mw7.8-8.3 and the 1927 AD Gulang

126 M8.0 earthquakes, ruptured these two faults (Deng et al., 1984; Gaudemer et al., 127 1995).

128 Several field studies along the Haiyuan fault have been carried out during the last 12930 years. For instance, paleoseismic investigations along the Haiyuan (e.g. Zhang et 
al., 1988b, 2003; Ran et al., 1997; Xiang et al., 1998; Min et al., 2001; Liu-Zeng et al.,

131 2015) and Maomao Shan (e.g. Yuan et al., 1998; Liu-Zeng et al., 2007) sections show

132 that earthquakes can rupture single or several sections together, and cluster temporally.

133 High-resolution deposition sequences in trenches also provided evidence of

134 magnitude 6 to 7 earthquakes (Liu-Zeng et al., 2015). Six events are documented on

135 the Lenglong Ling section from which the most recent may be related the 1927

136 Gulang M8.0 earthquake (Guo et al., 2019; Gaudemer et al., 1995).

137 Geological slip rates determined along the Haiyuan fault differ greatly, from a $138 \mathrm{few} \mathrm{mm} / \mathrm{yr}$ to more than $1 \mathrm{~cm} / \mathrm{yr}$, due to different dating approaches and slip 139 reconstruction models. For example, Lasserre et al. (2002) proposed a slip rate for the 140 Lenglong Ling segment based on a $\sim 200 \mathrm{~m}$ offset of a lateral moraine dated with 141 cosmogenic radionuclide $(\mathrm{CRN})$ of $19 \pm 5 \mathrm{~mm} / \mathrm{yr}$ with a lower bound of $11 \pm 3$ $142 \mathrm{~mm} / \mathrm{yr}$. Along the same Lenglong Ling section, He et al. (2000) argued for a lower 143 slip rate of 3.3-4.1 mm/yr based on older OSL dates. Recently, Jiang et al. (2017) 144 estimated a left-lateral slip rate of $6.6 \pm 0.3 \mathrm{~mm} / \mathrm{yr}$ along the eastern section of the 145 Lenglong Ling segment based on late Pleistocene ${ }^{14} \mathrm{C}$ and OSL ages of stream offsets. 146 Along the Maomao Shan segment, Lasserre et al. (1999) determined a slip rate of 12 $147 \pm 4 \mathrm{~mm} / \mathrm{yr}$, while Yuan et al. (1998) estimated lower slip rates of 4.1-5.4 mm/yr. Yao 148 et al. (2019) recently reassessed the offsets and age control for sites of Lasserre et al. 149 (1999) and updated the slip rate here to $5-8.9 \mathrm{~mm} / \mathrm{yr}$ over the late Pleistocene 150 Holocene. Further east, the Haiyuan segment, which ruptured in the 1920 Haiyuan 151 earthquake, was assigned a slip rate of $8 \pm 2 \mathrm{~mm} / \mathrm{yr}$ by Zhang et al. (1988b). Li et al. 152 (2009) updated this value to $\sim 4.5 \pm 1 \mathrm{~mm} / \mathrm{yr}$ by dating offset alluvial terraces. 153 Combining ${ }^{10} \mathrm{Be}$ CRN ages from surface and subsurface depth profiles in a set of 154 terraces, Matrau et al. (2019) constrained a minimum slip rate of $3.2 \pm 0.2 \mathrm{~mm} / \mathrm{yr}$ 155 along one of the fault strands crossing the Hasi Shan restraining bend, within the 156 western section of the 1920 Haiyuan earthquake rupture. 
and linked across a $6 \mathrm{~km}$-wide left step by a $\mathrm{N} 45^{\circ} \mathrm{E}$-striking and east dipping normal

159 fault, which bounds the Tianzhu half-graben or pull-apart basin in the west

160 (Gaudemer et al., 1995; Figure 2). The Jinqiang He section fault of striking $\mathrm{N} 110^{\circ} \mathrm{E}$

161 offsets alluvial fans and ridges along the northern side of the Jinqiang He valley.

162 There is no evidence of large earthquake during at least the past eight centuries along

163 these two fault sections, which are considered together as "the Tianzhu seismic gap"

164 (Gaudemer et al., 1995).

165 The site of Daqing (or Sangedun site in Gaudemer et al., 1995; Tapponnier et al., 166 2001b) is located along the eastern part of the Jinqiang He section, north of the 167 Honggeda village, and $\sim 80 \mathrm{~km}$ east of the sites investigated by Lasserre et al. (2002)

168 (Figure 2). The mountain range immediately to the north is locally called Leigong 169 Shan, with the highest peak reaching $4326 \mathrm{~m}$. Traces of the last glaciation, in the form 170 of fresh glacial cirques, are preserved above $3700 \mathrm{~m}$ on the southern flank of the 171 mountain range (Gaudemer et al., 1995). Streams incising the steep southern flank of 172 the mountains feed boulder-bearing fluvio-glacial fans that are cut near the apex by 173 the Haiyuan fault. Here, glacial moraines are absent, but to the west in the Lenglong 174 Ling area, glacial landforms are common (Meyer et al, 1998; Lasserre et al., 2002; 175 Owen et al., 2003). OSL and CRN ages of glacial deposits in the Lenglong Ling area 176 indicate that the Last Glacial Maximum (LGM) took place at 18-21 ka, in agreement 177 with the timing of global LGM (Owen et al., 2003; Wang et al., 2013). Following the 178 cold and arid glacial period, fans and terraces are emplaced in the late Pleistocene and 179 early Holocene, due to increase runoff and glacial melting as the climate became 180 warmer (e.g., Meyer et al., 1998; Van der Woerd et al., 2002; Hetzel, 2013). Climatic 181 index analysis at a site on the northern flank of the Leigong Shan suggested that it 182 was warm and wet in the early Holocene (9.6-9.0 ka B.P.), and the most arid period 183 during the Holocene occurred between 9.0-8.7 ka B.P., when loess was deposited at 184 the site (Wu et al., 1998). At a regional scale, loess deposition was common but 
spatially unevenly distributed in the Qilian Shan during the Holocene (Meyer et al., 1998; Küster et al., 2006; Zhang et al., 2015).

At the Daqing site, a stream that flows down from a high catchment (elevation $>4000 \mathrm{~m}$ asl) and perpendicular to the main fault has abandoned a set of 3 main terrace levels along its west bank (Figure 3). The terraces are cut and offset by the Haiyuan fault. Based on fieldwork, aerial-photo interpretation, and topographic leveling with a theodolite, Gaudemer et al. (1995) determined that the three main terraces are respectively offset horizontally by $143 \mathrm{~m}, 89 \mathrm{~m}$, and $35 \mathrm{~m}$ and vertically by $18 \mathrm{~m}, 11 \mathrm{~m}$, and $4 \mathrm{~m}$. Assigning an abandonment age of $13.5 \pm 2 \mathrm{ka}$ to the highest terrace based on the assumption that it was deposited and abandoned during the wetter and warmer period following the last glacial maximum, they proposed a slip-rate of $11 \pm 4 \mathrm{~mm} / \mathrm{yr}$.

\section{LEVELING AND GEOCHRONOLOGY METHODS}

We used a combination of terrestrial LiDAR (TLS), Uncrewed Aerial Vehicle (UAV) and kinematic GPS to survey the landforms of the Daqing site. For terrestrial LiDAR, we used a Riegl VZ-1000, with an effective scan range of $\sim 1400 \mathrm{~m}$ and a precision of $\sim 5 \mathrm{~mm}$. Three successive scans were needed to cover all the studied area. A Trimble real-time kinematic (RTK) Global Position system (GPS) surveyed the position and elevation of each scanning base. These positions were used to register the different point cloud datasets together. Because some places cannot be scanned by the TLS due to topographic roughness, we used a DJI ${ }^{\circledR}$ Phantom 2 drone equipped with a fixed focus camera to capture aerial imagery vertically and obliquely to generate an ortho-photo mosaic of the site by Structure-from-Motion techniques (e.g. James and Robson, 2012; Bemis et al., 2014) (Figures 3 and 4). The drone took more than 120 photos at a height of about $50 \mathrm{~m}$ above ground surface. The flight paths are parallel to the fault trace with a swath of $30-50 \mathrm{~m}$. We set up 6 ground control points (GCP) distributed evenly at the terrace surfaces before collecting photos. The 
213 positions of GCPs were recorded by GPS-RTK. Agisoft ${ }^{\circledR}$ Photoscan was used to 214 process the aerial photos and generate the ortho-photo covering the studied site. We 215 projected the DEM derived from the TLS point cloud in the same coordinates as the 216 ortho-photo (Figures 3 and 4). Three topographic profiles were leveled in the field 217 using the Trimble RTK-GPS system described above along the various terrace risers. 218 We also extracted topographic profiles from the high-resolution DEM as single 219 profiles or swath profiles. The profiles were projected either perpendicular or parallel 220 to the fault trace (Figures 4 and 5).

221 At the Daqing site, the terrace conglomerates in the piedmont of the Leigong 222 Shan are deposited as debris flows originating from the catchment up slope. The 223 clasts within these conglomerates may have been mobilized from moraines upstream, 224 which remnants are still visible in the upper part of the catchment (Figure 3). 225 Sediments mostly comprise granite, gneiss and metasedimentary rocks. Large 226 boulders $0.5-2 \mathrm{~m}$ in diameter armor the surface of the terraces, some of them are 227 partially buried due to loess accumulation and soil development. Quartz-rich rock 228 samples for terrestrial cosmogenic radionuclide (CRN) dating were collected from the 229 top of boulders using chisel and hammer (Figures 4 and 6). In addition, a pit was dug 230 into the highest terrace (T3) for sub-surface sampling (Figures 4A and 7). The upper $2311.1 \mathrm{~m}$ of the profile consist of $80 \mathrm{~cm}$ thick dark brown to black silty soil topping a 30 $232 \mathrm{~cm}$ silty (loess) layer mixed with sparse gravels and pebbles of less than $1 \mathrm{~cm}$ in grain 233 size. In these upper layers we sampled 2 radiocarbon samples of bulk soil at 62 and 77 $234 \mathrm{~cm}$ depths, and 2 OSL samples at 82 and $104 \mathrm{~cm}$ depths (Tables 1 and 2). In the lower 235 conglomeratic part of the profile, we collected 8 samples of amalgamated quartz-rich 236 gravels and pebbles (size $<5 \mathrm{~cm}$ ) down to $3 \mathrm{~m}$ depth for cosmogenic isotope dating. 237 All sample locations were recorded using a portable GPS and elevations were 238 adjusted with the topography data from the TLS (Figure 4; Table 3).

239 Radiocarbon samples were analyzed by Beta Analytic with accelerator mass 240 spectrometry (AMS) and calibrated using Calib 7.1 (Stuiver et al., 1993) (Table 1). 
241 The two OSL samples were processed and analyzed following Aitken (1998) and Lu

242 et al. (2007). Coarse-grained quartz was purified from samples through chemical

243 separation using 30\% $\mathrm{H} 2 \mathrm{O} 2,10 \% \mathrm{HCl}$, and $40 \% \mathrm{HF}$, and magnetic separation. The

244 ratio of Infra-red Stimulated Luminescence (IRSL) to Blue Light Stimulated

245 Luminescence (BLSL) has been checked to be lower than $45 \%$ to make sure the

246 quartz is clean. A Risø TL/OSL-DA-20 reader was used for irradiation, heating and

247 luminescence measurements (Table 2 and Figure 8). All dose rates were calculated

248 using a central age model (Galbraith et al., 2012).

249 The samples analyzed for ${ }^{10} \mathrm{Be}$ cosmogenic nuclide were pre-processed at the

250 Key Laboratory of Crustal Dynamics, China Earthquake Administration. We crushed

251 the gravels and pebbles, purified the 250-500 $\mu \mathrm{m}$ fraction with acid leaches to obtain

252 pure quartz, then used hydrofluoric acid to dissolve about $30 \mathrm{~g}$ of quartz to which a

253 Beryllium-9 carrier solution was added. We isolated beryllium hydroxide $(\mathrm{BeOH} 2)$

254 using cation exchange chromatography, which was then heated to $700^{\circ} \mathrm{C}$ to form

255 beryllium oxide $(\mathrm{BeO})$. Final targets were prepared at the Cosmogenic isotope

256 Laboratory of Institut de Physique du Globe de Strasbourg (CNRS, University of

257 Strasbourg) and processed at the ASTER-AMS facility of Centre Européen de

258 Recherche et d'Enseignement des Géosciences de l'Environnement (Aix-en-Provence,

259 France) for measurement (Table 3).

260

261 RESULTS

\section{Horizontal and vertical cumulative slip determination}

263 Combining the DEM with a resolution of $\sim 0.1 \mathrm{~m}$ computed from point clouds 264 acquired by TLS, the RTK-GPS topographic profiles, and the aerial orthophoto 265 mosaic acquired by UAV, we produce a geomorphic map of the Daqing site (Figure

266 4). Overall, our mapping and leveling are consistent with previous interpretation of 267 the site by Gaudemer et al. (1995). Three main terrace levels are abandoned and 268 preserved on the west bank of the Daqing stream. These are offset both horizontally 
269

270

271

272

273

274

275

276

277

278

279

280

281

282

283

284

285

286

287

288

289

290

291

292

293

294

295

296

and vertically due to oblique fault slip. The trace of the main Haiyuan fault can be clearly followed along the steepest part of the topographic scarp trending $\mathrm{N} 110^{\circ} \mathrm{E}$. The fault trace is also marked by roughly aligned large blocks across the active stream bed, as already noted by Gaudemer et al. (1995), which are clearly visible on the aerial photo and in the field (Figure 3).

The terrace levels are well defined and separated by steep risers (Figures 4 and 5; Table 4). The terrace surfaces slope southward $14^{\circ}$ to $8^{\circ}$ from oldest to youngest, reflecting progressive incision and lower depositional gradient of younger deposits (Figures 4 and 5). The highest terrace level T3 is located to the west of the active riverbed. It is cut and offset by a 15-19 m-high south facing scarp. The intermediate terrace level is subdivided between older and higher standing parts, labeled T2, which are characterized by sparse outcropping boulders, and down to $6 \mathrm{~m}$-deep channels, labeled T2', locally stranded by small terrace remnants designated T2' (Figures 4 and 5). The lowest terrace level $\mathrm{T} 1$ stands a few meters above the active riverbed. At places, gullying and riser-slope instabilities have added some disturbance to the overall simple geomorphological setting. The height and width of the fault scarp is larger on the older terraces than on the younger ones, due to additional accumulated deformation and progressive degradation of the steep fault scarp (Figures 3 and 4) (e.g., Tapponnier et al., 1990; Zinke et al., 2015). In addition, due to relative vertical motion on the fault, terrace-riser height is larger upstream than downstream with no significant average slope change (Figure 5).

Because of lateral stream erosion and local degradation of terrace risers, terrace edges are not linear features, which lends uncertainty to reconstruction of their geometry prior of being offset. Downstream risers T3/T2' and T2/T1 are curved near the fault trace (Figures 3 and 4), which suggests that displacement of the risers started to accumulate before the lower terrace levels were completely abandoned. A number of studies have addressed the interaction between geomorphic processes and tectonic movement to determine whether terrace riser or channel offsets are true tectonic 
297 offsets (e.g., Lensen, 1964; Gaudemer et al., 1989; Van der Woerd et al., 2002;

298 Cowgill, 2007; Mériaux et al., 2012; Reitman et al., 2019). To address the difficulty

299 of offset determination from geomorphic features we thus determined multiple offsets

300 for each riser, using both far- and near-field projections to the fault, and both the top

301 and bottom edges (Figure 9).

302 We determined displacement values by fitting far-field riser edges (more than

$303100 \mathrm{~m}$-long and several 10s of m away from fault trace) and near-field riser edges (a

304 few 10s of m-long and near the fault trace) across the fault. Terrace risers reach up to

$30520 \mathrm{~m}$ height and display slopes of $10-40^{\circ}$, so that offsets related to riser top and

306 bottom are also specified, especially offsets of curved risers near fault trace (Figures 4

307 and 9; Table 4). It is worth pointing out that the far-field displacements of risers (e.g.,

308 D3t, D3b, D2t, D2b) are likely related to the abandonment of the adjacent upper

309 terrace, while near-field displacements (e.g., d3t, d3b, d2t, d2b) (Figure 9F) are likely

310 related to the adjacent lower terrace.

311 For the terrace riser top T3/T2', its upstream nonlinear part may be fit in two 312 ways. Either the piercing line fits tangentially the two lower convexities to the east or 313 the higher concavities to the west (Figure 4A). Downstream, the far-field piercing line 314 is perfectly linear about $60 \mathrm{~m}$ away from the fault. Far-field piercing lines of riser 315 base T3/T2' are almost parallel to the top on both side of the fault. Correlating riser 316 top piercing lines yield displacements of $82 \pm 3$ to $94 \pm 3 \mathrm{~m}$ (this latter measurement 317 being similar to the $101.5 \mathrm{~m}$ of Gaudemer et al., 1995) or, on average, $88 \pm 9 \mathrm{~m}$. 318 Piercing lines at base of riser constrain an offset of $72 \pm 3 \mathrm{~m}$. The near-field riser 319 T3/T2' is curved both upstream and downstream of the fault. We can match riser top $320(\mathrm{~d} 3 \mathrm{t})$ and base (d3b) with similar values of $25 \pm 2$ and $28 \pm 2 \mathrm{~m}$ (Figure 4, Table 4).

321 West of $\mathrm{T} 2$, the eastern limit of channel T2', or the base of riser T2/T2' is only 322 determined in the near-field. Its offset of $29 \pm 2 \mathrm{~m}$ is similar and consistent with $\mathrm{d} 3 \mathrm{~b}$ $323(28 \pm 2 \mathrm{~m}$ ) (Figure 4, Table 4). East of T2, far-field riser top T2/T1 is linear upstream 324 of the fault and about $30 \mathrm{~m}$ downstream of the fault. The far-field riser base is almost 
parallel to the riser top. The offsets of riser T2/T1 top and base are $35 \pm 2 \mathrm{~m}$ and $27 \pm$

$3262 \mathrm{~m}$, respectively, or on average $31 \pm 4 \mathrm{~m}$. The near-field riser T2/T1 is curved, 327 particularly downstream of the fault, and its near-field riser top (d2t) and base $(\mathrm{d} 2 \mathrm{~b})$

328 are similarly offset $6.5 \pm 1 \mathrm{~m}(\mathrm{~d} 2 \mathrm{t}$ and $\mathrm{d} 2 \mathrm{~b}$, Figure 4 , Table 4$)$. A small incision in the 329 middle of terrace T1 is also offset by $6.0 \pm 0.5 \mathrm{~m}$ (Figures 4 and 10). Near the fault, 330 riser $\mathrm{T} 1 / \mathrm{T} 0$ does not preserve lateral slip, even though $\mathrm{T} 1$ and $\mathrm{T} 0$ have been ruptured 331 in the past as indicated by the vertical offset of $\mathrm{T} 1$ and the visible fault trace across T0 332 (Figures 3C and 4). Away from the fault, the far-field riser T1-T0 seems left-laterally 333 offset by several meters, although lateral erosion from the still active stream cannot be 334 excluded (Figures 4 and 9).

335 In summary, both sets of terrace risers T3-T2' and T2-T1 show a similar pattern 336 where far-field riser top offsets are much larger than near-field riser base offsets, $337 \quad 79-97 \mathrm{~m}$ versus $23-30 \mathrm{~m}$ and 33-37 $\mathrm{m}$ versus 5.5-7.5 $\mathrm{m}$ (Figure 4A). This observation 338 suggests that far-field riser top offset ages are close to the age of the upper terrace, 339 although it remains a maximum age and that the near-field riser base offset ages are 340 close to the age of the lower terrace. Therefore, $88 \pm 9 \mathrm{~m}$ can be defined as a lower 341 bound for the horizontal offset of T3. The bounds of the offset of T2 range between $34272 \pm 3 \mathrm{~m}$ and $35 \pm 2$, but probably closer to the upper bound because the channel T2' 343 offset is well constrained at $28-29 \pm 2 \mathrm{~m}$. Finally, the offset of T1 is well constrained 344 at 6-6.5 $\pm 1 \mathrm{~m}$ from the similar values of the near-field riser base offset and the 345 incision across T1 (Table 4).

346 In addition to left-lateral horizontal slip, the Haiyuan fault exhibits a vertical 347 component of slip at this site (Figures 3, 4 and 5). The scarp height measured along 348 the swath profile $\mathrm{C} 1-\mathrm{C} 1$ ' in the middle of terrace T3 $(19 \pm 2 \mathrm{~m})$ is larger than the 349 height from the profile $\mathrm{C}-\mathrm{C}^{\prime}$ following the terrace edge $(15 \pm 2 \mathrm{~m})$ (Figures 4 and 5).

350 This discrepancy is due to lateral displacement of the oblique slope terrace T3 relative 351 to the fault trace (e.g., Peltzer et al., 1988; Gaudemer et al., 1995; Rodgers and Little, 352 2006; Chevalier et al., 2016). Correcting the measured offset of $19 \pm 2 \mathrm{~m}$ (Vi) by 
taking into account the slope of terrace T3 (on average $3.1^{\circ}$ to west parallel to $\mathrm{N} 110^{\circ}$ E striking fault trace, see profiles D2, E1-3 in Figure 5) and a horizontal offset of $88 \mathrm{~m}$ yields a corrected vertical offset of $14 \pm 2 \mathrm{~m}(\mathrm{Vr})$ similar to the value of $15 \pm$ $2 \mathrm{~m}$ from the offset-riser top. Maximum slopes of terrace T2 on both sides of the fault are similar and oriented perpendicular to fault trace, so that no correction is needed for T2 and its vertical throw is $10 \pm 1 \mathrm{~m}$ Figure 5, Table 4). The terrace level T2' slopes on average perpendicular to the fault trace and its vertical offset ranges from $5.7 \pm 1 \mathrm{~m}$ (profile B1-B1') to $6.4 \pm 1 \mathrm{~m}$ (profile B-B'), thus on average $6.0 \pm 1.5 \mathrm{~m}$ (Figure 5, Table 4). The slopes of T1 are similar upstream and downstream and the height of the fault scarp across $\mathrm{T} 1$ is $1.3 \pm 0.2 \mathrm{~m}$ (Figure 5).

To summarize, the 4 terraces T3, T2, T2' and T1 at the Daqing site have horizontal and vertical offsets of $88 \pm 9 \mathrm{~m}, 33-75 \mathrm{~m}, 28.5 \pm 2 \mathrm{~m}, 6.0 \pm 0.5 \mathrm{~m}$ and $15 \pm$ $2 \mathrm{~m}, 10 \pm 1 \mathrm{~m}, 6.0 \pm 1 \mathrm{~m}, 1.3 \pm 0.2 \mathrm{~m}$, respectively (Table 5). These values display a consistent vertical to horizontal ratio that ranges from 0.170 to 0.211 (average $0.191 \pm$ 0.018; Table 5) testifying of a constant slip vector overall (Figure 11).

\section{Terrace ages}

To constrain the age of abandonment of T3, we dug a $3 \mathrm{~m}$-deep pit in the downstream tread of terrace T3 (Figure 3). The upper $1.1 \mathrm{~m}$ of the profile exhibit a 30 $\mathrm{cm}$ sandy-loessic layer overlain by an $80 \mathrm{~cm}$-thick dark brown silty soil, which partly developed by incorporating wind-blown loess and sand. Below $1.1 \mathrm{~m}$ depth, the profile penetrates the conglomeratic terrace deposit consisting of boulders, cobbles, gravels and sand. Two OSL samples from the loess layer yield ages of 12.2 and $8.7 \mathrm{ka}$ in stratigraphic order (Figure 7, Table 2). Two radiocarbon samples from the lower part of the soil yield ages of 7.7 and $7.6 \mathrm{ka}$, also in stratigraphic order (Figure 7, Table 1). Whether the loessic layer is of aeolian origin or reworked loess in overbank deposits cannot be confirmed. In any case, the $1.1 \mathrm{~m}$-thick top layer of the terrace indicates deposition processes incompatible with the presence of an active stream and 
381 thus it indicates that the underlying conglomerate has been abandoned prior to 382 deposition of these upper layers, i.e., prior to $12.2 \mathrm{ka}$. To better constrain the age of 383 abandonment of the terrace, we modeled the ${ }^{10} \mathrm{Be}$ concentration with depth for 8 384 amalgamated samples of gravel and pebbles collected from the conglomeratic terrace 385 deposit (Figure 7, Table 3). To take into account the shielding effect of the loess and 386 soil we propose 3 end-member models (Figure 12A). The first one (model 1) is a 387 maximum-shielding or maximum-age model, for which despite knowledge of the 388 loess and soil ages from other methods (OSL and ${ }^{14} \mathrm{C}$ ), we consider that loess and soil 389 were deposited immediately after the abandonment of the conglomerate forming T3 390 (Figure 12A). Considering the respective density of 2.0 for sandy-loess and of 1.2 for 391 soil, the best fit of the ${ }^{10} \mathrm{Be}$ data is obtained with an exposure age of $21.6 \pm 4.6 \mathrm{ka}\left(\mathrm{t}_{1-1}\right)$ 392 (Figure 12D). Clearly, given the age of the lowermost OSL sample of $12.2 \mathrm{ka}$, this 393 age is not realistic and implies stepwise or progressive emplacement of the 394 sandy-loess and soil layers, which we consider in the following models. A second 395 model (model 2) takes into account the oldest ages of the sandy-loess and soil deposit 396 as the moment when these layers were deposited (Figure 12B). This model has thus 3 397 exposure phases, a first one corresponding to the abandonment of the conglomerate 398 without shielding (between $\mathrm{t}_{2-1}$ and $\mathrm{t}_{2-2}$ ); a second one, with $30 \mathrm{~cm}$ of sandy-loess 399 shielding starting at $12.2 \mathrm{ka}\left(\mathrm{t}_{2-2}\right)$; and a third one, with the additional $80 \mathrm{~cm}$ of soil 400 shielding starting at $7.7 \mathrm{ka}\left(\mathrm{t}_{2-3}\right)$. The sandy-loess and soil layers are assumed to have 401 been deposited instantaneously. Model 2 gives a time of exposure of the conglomerate 402 without shielding of $2.7 \mathrm{ka}$, thus an abandonment age of $14.9 \mathrm{ka}\left(\mathrm{t}_{2-1}\right)$ (Figure 12E). A 403 third model (model 3), is similar to model 2 but instead of considering an 404 instantaneous deposition of the sandy-loess and soil layers, it considers progressive 405 deposition of the shielding layers: $30 \mathrm{~cm}$ of loess deposited between $12.2 \mathrm{ka}$ and 7.6 $406 \mathrm{ka},(6.5 \mathrm{~cm} / \mathrm{ka})$ and $80 \mathrm{~cm}$-thick soil deposited between $7.6 \mathrm{ka}$ until today $(10.5 \mathrm{~cm} / \mathrm{ka})$ 407 (Figure 12C). Model 3 is a minimum shielding model or minimum age model and 408 gives an abandonment age of $13.7 \mathrm{ka}\left(\mathrm{t}_{3-1}\right)$. The result of the third model is compatible 
with all age data, and we thus suggest an abandonment age for terrace T3 of $13.7 \pm$ 1.5 ka (Figure 12F).

For terraces T2 and T1, we collected surface exposure samples made of pieces of the top of large, 0.8 to $2 \mathrm{~m}$ in diameter, well embedded boulders (Figures 4 and 6, Table 3). As visible on sample field views in Figure 6, the boulders are variable in size, in height above soil surface and also in overall shape ranging from well-rounded to angular. Despite inspection of the boulders it cannot be ascertained that they have not suffered alteration or spallation. We thus sampled a large number of boulders and selected the best-preserved parts at the top of the boulders (Figure 6, Table 3). Seven samples were collected on terrace T2 south of the fault; six samples were collected on terrace $\mathrm{T} 1$, three to the north and three to the south of the fault (Figure 4, Table 3). Both ${ }^{10} \mathrm{Be}$ concentration distributions of the samples collected on $\mathrm{T} 2$ and $\mathrm{T} 1$ indicate a large scatter in the data, with overlapping values between terraces (Figure 12G). This scatter may be related to unevenly distributed and large inheritance among the boulders and/or variable erosion affecting the protruding large boulders at the surface of the terraces (e.g., Ritz et al., 2006; Ryerson et al., 2006; Le Dortz et al., 2011). Such ${ }^{10} \mathrm{Be}$ concentration scatter is a common feature of boulders originating from small size high-mountain glacial catchments where accumulation and transport vary with climate changes (e.g., Putkonen and Swanson, 2003; Heimsath and McGlynn, 2008; Heyman et al., 2011). Boulders may have sat at various depths in moraines upstream at high elevation during a large part of the Pleistocene, before being transported episodically, thanks to increased moist periods and during brief flash floods. Unlike large catchments with deep valley fill, most of the conglomerate forming part of fans and terraces at the outlet of the upper valley across the fault zone were probably never buried deep enough to be shielded completely from cosmic rays. The deepest gravels in the T3 depth profile have concentrations representing about 20 to $30 \%$ of the surface samples, which represent a significant amount of inherited ${ }^{10} \mathrm{Be}$ acquired upstream. This amount of inheritance may be indicative of the intermittent 
437 stream dynamics and evidence of sediment accumulation in the catchment.

438 Inheritance may be distributed differently in amalgamated gravels and large boulders, 439 as their mode of transport and residence time in the catchment differ greatly (e.g., 440 Benedetti and Van der Woerd, 2014; Carretier et al., 2015). Assuming that the scatter 441 is due to inheritance, the boulders with minimal inheritance are thus closest to the true 442 surface age (e.g., Le Dortz et al., 2011; Owen et al., 2011; Prush and Oskin, 2020). 443 For terrace T2, sample HGD14-27 has the lowest ${ }^{10} \mathrm{Be}$ concentration and an exposure 444 age of $11.8 \pm 1.1 \mathrm{ka}$. (Figure $12 \mathrm{G}$, Table 3 ). Note that this age is younger but close to 445 the age of the upper terrace T3 $(13.7 \pm 1.5 \mathrm{ka})$ and may be considered a maximum age. 446 Additional age constraints for T2 may be given by radiocarbon dates of the overlying 447 soil from the study of Liang et al. (2018). The ages obtained in two pits in the top soil 448 of terrace T2 upstream and downstream of the fault indicate that T2 must have been 449 abandoned before $9.3 \pm 0.6 \mathrm{ka}$ (Figure 4, Table 1). Thus, the age of terrace T2 may be 450 bracketed between $9.3 \pm 0.6$ and $11.8 \pm 1.1 \mathrm{ka}$.

451 For terrace $\mathrm{T} 1$, the scatter in ${ }^{10} \mathrm{Be}$ data of the 6 surface samples is similar as for 452 terrace T2, but the range of concentrations is lower. Making similar assumptions 453 about the origin of the scatter, the sample with the lowest ${ }^{10} \mathrm{Be}$ concentration should 454 be close to the true age of the terrace. The lowest concentrated sample is HGD14-23 455 with an exposure age of $1.2 \pm 0.1 \mathrm{ka}$ (Figure $12 \mathrm{G}$, Table 3 ). In the absence of better 456 age constraints, we assume that the age of terrace T1 is close to $1.2 \pm 0.1 \mathrm{ka}$.

457

458 Slip rate

459 Dividing the lower bound of the cumulative displacement of terrace T3, defined 460 by the terrace T3/T2' riser top offset of $88 \pm 9 \mathrm{~m}$ by the abandonment age of T3 of $461 \quad 13.7 \pm 1.5 \mathrm{ka}$ yields a minimum left-lateral slip rate of $6.5 \pm 1 \mathrm{~mm} / \mathrm{yr}$. The bounds of 462 the offset of terrace T2 of $72 \pm 3 \mathrm{~m}$ and $35 \pm 2 \mathrm{~m}$ accumulated after $9.3 \pm 0.6-11.8 \pm$ $4631.1 \mathrm{ka}$ yield a rate of $5.7 \pm 2 \mathrm{~mm} / \mathrm{yr}$. T2' channel offset of $28.5 \pm 2 \mathrm{~m}$ remains undated 
464 in the absence of ages for T2'. And taking the age of $1.2 \pm 0.1 \mathrm{ka}$ for terrace T1 and

465 its $6.0 \pm 0.5 \mathrm{~m}$ offset yields a slip rate of $5.0 \pm 0.9 \mathrm{~mm} / \mathrm{yr}$ (Figure 13; Table 5).

466 The observation of a near constant slip vector at the Daqing site (Figure 11) and 467 using the better determined vertical offset of the terraces (Table 5), we may estimate 468 the age of terrace T2' from its vertical offset of $6.0 \pm 1.5 \mathrm{~m}$ and the age of T3, 469 yielding $5.4 \pm 1.0 \mathrm{ka}$. Similarly, the age of T1, vertically offset $1.3 \pm 0.2 \mathrm{~m}$, may 470 be estimated at about $1.2 \pm 0.2 \mathrm{ka}$, concordant with our assumption that it may be 471 dated with the youngest surface boulder age $(1.2 \pm 0.1 \mathrm{ka}$; Table 3$)$. The same 472 relations may be used to further constrain the loosely determined horizontal offset of 473 terrace T2, which is thus likely offset about $51 \mathrm{~m}$, an offset not preserved at the 474 Daqing site, probably due to lateral erosion of the lower terrace.

475

\section{DISCUSSION AND IMPLICATION}

\section{Diachronous riser formation}

478 Geologic slip rate reflects faulting behavior over the long term. Geologic rates are 479 a basic datum for understanding strain accommodation through a system of faults and 480 also one of the most important indicators for earthquake potential of a fault. 481 Considerable efforts have been devoted to determining the slip rate on active faults in 482 and around the Tibetan Plateau. Although determination of a geologic fault slip rate is 483 simple in principle, it is subject to considerable uncertainty. The difficulty lies in the 484 fact that the duration of offset accumulation is often approximated by a surrogate age. 485 Indeed, terrace risers are commonly used as offset features in slip rate determination 486 of faults in northern Tibet, including the Haiyuan, the Altyn Tagh and the Kunlun 487 faults (e.g., Peltzer et al., 1989; Meyer et al., 1996; Van der Woerd et al., 1998, 2000, 488 2002; Lasserre et al., 1999; Mériaux et al., 2004, 2005, 2012; Kirby et al., 2007; 489 Cowgill, 2007; Cowgill et al., 2009). These are erosive features, which likely form 490 diachronously, starting to record offset after the abandonment of the upper terrace and 491 sometimes before the abandonment of the lower terrace (e.g., Ryerson et al., 2006; 
492 Harkins and Kirby, 2008; Gold et al., 2009; Mériaux et al., 2012). For a given terrace

493 riser offset, the abandonment age of the upper terrace surface provides the maximum

494 age of slip accumulation, thus the lower bound of the true slip rate. Accordingly, the

495 lower terrace surface age represents the minimum age of slip accumulation and thus

496 the upper bound of the slip rate.

497 Terrace riser preservation results from the interaction between river erosion and

498 displacement by the fault. In general, a terrace riser on the left bank of a river crossing

499 a left-lateral fault is protected, i.e., continuous left-lateral slip moves the downstream

500 section of the riser away from the stream center and is less frequently refreshed, thus

501 more likely to record offset before the abandonment of the lower terrace (e.g.,

502 Cowgill, 2007). On the contrary, left-lateral slip on the fault is moving the

503 downstream part of the right bank riser toward the center and in alignment with the

504 upstream channel. This configuration favors more frequent riser refreshment and

505 obliteration of offset before the abandonment of the lower terrace (e.g., Van der

506 Woerd et al., 1998; Tapponnier et al., 2001a, b). However, our investigation at the

507 Daqing site shows incomplete riser refreshment and slip accumulation before the

508 lower terrace is abandoned. Our mapping and offset measurements of the sequentially

509 abandoned terrace surfaces suggest that the right-bank terrace risers, i.e., erosive side,

510 are subject to incomplete riser refreshment and partial preservation of riser offset.

511 Several reasons may explain this situation at the Daqing site. First, the obliquity in

512 slip vector and the accumulation of vertical displacement on the fault induces more

513 incision in the upstream parts of the terraces (Figures 4 and 5), increasing channeling

514 upstream and possibly less erosion downstream. Second, the main river trunk may

515 have reduced its width progressively with time and remained channeled on the eastern

516 side of the terraces, thus favoring preservation of the accumulated offsets.

517

518 Upper and lower bounds of the slip rate 
The differences between geological slip rates from previous studies along the

520 Haiyuan fault stem mainly from this uncertainty of using upper terrace surface versus

521 lower terrace surface ages as the surrogate for the true offset age of the terrace riser.

522 On one hand, Lasserre et al. (1999) reported a rate of $12 \pm 4 \mathrm{~mm} / \mathrm{yr}$ on the eastern

523 Maomao Shan section of the Haiyuan fault. They used the lower terrace age, i.e., the

524 minimum age for offset accumulation, thus provided an upper bound for the slip rate.

525 On the other hand, much lower slip rates were reported, such as 3.1-5.8 $\mathrm{mm} / \mathrm{yr}$ on the

526 Laohu Shan section (Yuan et al., 1998; Liu et al., 2018). These lower rates are based

527 on the upper terrace surface age for slip accumulation, and thus provide a lower

528 bound of the slip rate. As the many slip-rates of the Haiyuan fault shows, studies

529 finding a rate of $\leq 5 \mathrm{~mm} / \mathrm{yr}$ are mainly based on an upper terrace reconstruction. In

530 only a few cases both the upper and lower terraces were dated ( $\mathrm{Li}$ et al., 2009; Zheng

531 et al., 2013). If the lower terrace reconstruction scenario is considered in these studies,

532 an upper bound in the range of $4.5-22 \mathrm{~mm} / \mathrm{yr}$ is implied, even though this upper

533 bound is not mentioned. An objective evaluation of these two previous studies shows

534 that their authors sampled the loess cover (either OSL or ${ }^{14} \mathrm{C}$ dating) of the upper

535 terrace surface, which likely postdates the abandonment of the terrace surface. The

536 implication is that even though the upper terrace constrains the maximum age of

537 offset accumulation, the loess cover age shifts the terrace age towards lower values.

538 Therefore, several slip rates documented in previous studies have in fact larger

539 uncertainties than asserted.

540 Strictly speaking, the true slip rate of the Haiyuan fault should lie between the 541 ranges of upper and lower bounds. It is helpful to resolve the variability to explicitly

542 distinguish the lower and upper bounds when reporting the rate. At the Daqing site in 543 this study, the upper and the lower bounds of the slip rate, constrained by the offset of 544 the T3/T2 terrace riser and the respective upper and lower terrace ages, are similar, $5456.5 \pm 1 \mathrm{~mm} / \mathrm{yr}$ and $7.7 \pm 0.6 \mathrm{~mm} / \mathrm{yr}$. This is because the ages of T3 $(13.7 \mathrm{ka})$ and T2 $546 \quad(9.3-11.8 \mathrm{ka})$ are relatively close in time. 
The terrace riser $\mathrm{T} 2 / \mathrm{T} 1$ offset of $35 \mathrm{~m}$ provides a much larger uncertainty and

548 looser constraint on the slip rate (3.3-29.1 mm/yr) (Figure 13). The contrast in slip

549 rates bracketed by T3/T2 and T2/T1 at the same site highlights again that one should

550 not favor the upper or the lower terrace reconstruction scenarios, without additional

551 information. If we use the upper terrace age as the offset age, the offset of T3/T2 riser

552 suggests a slip rate of $6.5 \mathrm{~mm} / \mathrm{yr}$ (since $13.7 \mathrm{ka}$ ), whereas the offset of T2/T1 riser

553 suggests $3.3 \mathrm{~mm} / \mathrm{yr}$ (since 9.3-11.8 $\mathrm{ka}$ ), only half as much. This difference at the same

554 site could be interpreted as a temporal change in slip rate, as has been suggested

555 elsewhere for the Haiyuan or other faults (e.g., Weldon et al., 2004; Gold et al., 2011b,

556 2017a; Liu et al., 2018). In reality, the rates may be simply the lower and upper

557 bounds, rather than the true slip rates. The rate difference may be an indication of the

558 variable initiation time of riser offset record after the abandonment of the upper

559 terrace, thus the uncertainty in slip rate determination, rather than an indication of

560 temporal change in slip behavior. Comparison between short- and long-term slip rates

561 for a number of large strike-slip faults globally suggests that the slip rate does not

562 change significantly through time (Cowgill et al., 2009; Meade et al., 2013; Tong et al,

563 2014).

564

565 Reducing uncertainty in slip rate estimate from terrace riser offsets

566 Terrace riser offsets may be measured in several ways to reduce uncertainties in

567 slip rate. Although we can adopt both upper and lower terrace models to bracket a 568 conservative slip rate range instead of seeking a true rate (Cowgill, 2007; Cowgill et

569 al., 2009), large differences in the ages of the upper and lower terrace can produce

570 wide range of slip rates (e.g., Mériaux et al., 2012; Gold et al., 2017b). One way of

571 reducing the uncertainty in slip rate is to lower the uncertainty in displacement bounds.

572 In general, one measures offset riser paired tops (e.g., Hubert-Ferrari et al., 2002;

573 Rizza et al, 2011; Gold et al, 2011a) or middle parts (e.g., Mason et al., 2006; Carne

574 et al, 2011) because of poor preservation of riser bases, which are locations of debris 
accumulation (Stewart et al., 2018), or use full displacement range from top, middle and base of riser (Gold et al, 2017b). In all cases, dividing such displacements by the ages of the lower terraces yields the high upper bounds of the slip rate.

The offset of the riser base is sometimes smaller than the offset of the riser top, like at our Daqing site and observed elsewhere (e.g., Gold et al. 2017b). In this case, rates determined by correlating the offset riser top and base with the ages of the upper and lower terraces, respectively, are more consistent, implying a vertical diachronicity. As illustrated in Figure 9G, the near-field offset is preserved after abandonment of the lower terrace when the stream has not totally refreshed the riser. The age of the lower terrace is close to or older than the time when the near-field displacement starts to accumulate. The rate between the near-field offset and the age of the lower terrace abandonment may be close to the true slip rate although strictly a lower bound (e.g. Mason et al., 2006; Zinke et al., 2017).

The advantage of multiple paired offset terraces to resolve such issues has long been demonstrated (e.g., Lensen, 1964; Sieh and Jahns, 1984; Weldon, 1986; Gaudemer et al, 1995; Van der Woerd et al., 1998, 2002). Considering a set of independently determined slip-rates at a single site makes it possible to average the variability of river incision or lateral erosion with time. At the Daqing site, the set of 4 terrace levels allow such approach. In our study, due to difficulties in determining the precise age of all the terrace levels, we nevertheless constrained their relative ages using one well-determined terrace age and their respective horizontal and vertical offsets.

Finally, to avoid the ambiguity in correlating terrace surface ages with their upper or lower risers, the offset of the terrace itself may be determined (e.g., Lensen, 1964; Peltzer et al., 1988, 2020). In general, this is possible when the terraces bear particular syndepositional geomorphic markers at their surface (channels, ridges) or if the terraces have specific inherited shapes (fan shapes, slopes) that enables unambiguous geometric reconstructions. 


\section{Stable slip vector with time}

605 The assumption of uniform slip rate over time implies that the average slip 606 vector should be temporally stable. Thus, the ratio of vertical and horizontal offsets

607 should also be constant for all terraces (Figure 11; Table 5). The vertical offset of 15 $608 \pm 2 \mathrm{~m}$ and the minimum horizontal offset of $88 \pm 9 \mathrm{~m}$ on T3 imply a maximum ratio 609 of $0.170 \pm 0.029$. The ratios are $0.185 \pm 0.068,0.211 \pm 0.05$ and $0.2 \pm 0.07$ for T2, T2' 610 and T1, respectively. We consider an average ratio of $0.191 \pm 0.018$ consistent with 611 the range of ratios for the four terraces (Figure 11). This is larger than the ratio of $6120.125 \pm 0.025$ estimated by Gaudemer et al. (1995) at this site, due to a determination 613 of a larger total horizontal displacement of the upper terrace $(\mathrm{T} 3,145 \mathrm{~m})$ based on the 614 geometrical reconstruction of the terrace from a small number of topographic profiles. 615 Our terrace reconstruction, based on more exhaustive and high-resolution topographic 616 data, suggests a smaller total horizontal offset for terrace T3 and a larger average ratio, 617 consistent with the other terrace offsets (Table 5). When combining the ratio of 0.191 $618 \pm 0.018$ and the vertical offset of $10 \pm 1 \mathrm{~m}$ of $\mathrm{T} 2$, we can estimate the total horizontal 619 displacement of T2 to about $51 \pm 10 \mathrm{~m}$, an offset larger than the T2/T1 riser offset (35 $620 \pm 2 \mathrm{~m})$, but smaller than the T3/T2' riser offset $(72 \pm 3 \mathrm{~m})$. Although both the age and 621 horizontal offset of T2 are not well determined, the fact that a $51 \mathrm{~m}$ offset is not 622 preserved further supports lateral erosion of the T2/T1 riser after abandonment of T2 623 but prior to abandonment of $\mathrm{T} 1$.

624 Following the assumption of a temporally constant slip vector, our summary of 625 measured offsets versus corresponding ages (Figure 13) is compatible with a 626 temporally uniform strike slip rate of 5-8 mm/yr at this site (Table 5). The tightly 627 constrained age of T3 and the far-field offset of the lower riser top (solid rectangle in 628 Figure 13) strongly constrain this rate better than the other less well determined data 629 (dashed rectangles in Figure 13).

630 


\section{Comparison with geodetic rates}

It is tempting to favor the lower bound estimates for the Haiyuan fault slip rate, as it is closer to the geodetic rates from GPS data data $(4-5 \mathrm{~mm} / \mathrm{yr}$; Li et al, 2009) or from InSAR data (4-8 mm/yr; Cavalié et al., 2008; Jolivet et al., 2013; Daout et al., 2016), as for the Altyn Tagh fault (Cowgill, 2007; Zhang et al., 2007; Gold et al., 2009, 2011a). However, higher GPS or InSAR rates of $8.6 \mathrm{~mm} / \mathrm{yr}$ were also reported on the Haiyuan fault (Gan et al., 2007) and along the central section (Daout et al., 2016). Furthermore, discrepancies between geologic and geodetic slip rate were found on other faults, such as the San Andreas fault (Chuang et al, 2011; Johnson, 2013) and the Lazio-Abruzzo fault zone in Central Italy (Papanikolaou et al., 2005).

These results remind us that the current GPS data is not targeted for optimal determination of fault slip rate, because instrumented sites are still sparse, and thus the strain rate across single faults must be estimated by collapsing measurements within a wide (often $100 \mathrm{~km}$ wide) swath. When doing so, the effects of fault geometry changes or fault interactions along strike are not taken into account. Overall, the best determined rate at the Daqing site $(6.5 \pm 1 \mathrm{~mm} / \mathrm{yr})$ falls within the range of geodetic rates (4-9 mm/yr) estimated for the Haiyuan fault system.

\section{Earthquake rupture implication}

The youngest faulted terrace T1 with its inferred age of $1.1 \pm 0.1 \mathrm{ka}$ implies that the age of the most recent rupture at this site is even younger. At Daqing site, if terrace $\mathrm{T} 1$ and the stream bed $\mathrm{T} 0$ experienced only one rupturing event, as also speculated by Gaudemer et al. (1995), with the scarp across T0 being almost completely eroded, the offset of $\sim 6 \pm 0.5 \mathrm{~m}$ of the abandoned stream channel present on $\mathrm{T} 1$ and also the smallest lateral offset measured at the Daqing site may be considered as representative of the coseismic lateral slip of the last event. Combining the long-term slip rate of 5-8 mm/yr and this coseismic offset, the recurrence interval for such event would be $1100 \pm 300 \mathrm{a}$. 
Previous paleoseismological work along fault segments adjacent to Jinqiang $\mathrm{He}$ segment concluded to similar values for large earthquake recurrence. For the

661 Lenglong Ling section west of our site, mean Holocene recurrence intervals of $1430 \pm$ 662140 years (Jiang et al., 2017) and $1640 \pm 570$ years (Guo et al., 2019) are derived 663 from trench investigations. To the east of our site, paleoseismological investigations 664 showed that the Laohu Shan section seemingly ruptures every $\sim 1000$ years (Yuan et 665 al., 1997; Liu-Zeng et al., 2007). However, only one event (after $3500 \pm 200$ years 666 B.P.) was identified in a trench along the Jinqiang He section (Yuan et al., 1997). 667 While more paleoseismological investigations are necessary to identify and date 668 precisely the last large rupturing events along the Jinqiang He section of the Haiyuan 669 fault, existing data and our inference from terrace T1 at Daqing site, concur to the 670 occurrence of a large event in the last 1000 years and possible return times of $671 \quad 1000-2000$ years for large earthquakes.

672 The Jinqiang He section is about $55 \mathrm{~km}$ long. If this section ruptures entirely the 673 magnitude could reach up to Mw 7.1, or if a maximum coseismic displacement of $6 \mathrm{~m}$ 674 is considered, the magnitude could reach up to $\mathrm{Mw} 7.4$ according to empirical 675 relationship between surface rupture length, maximum displacement and magnitude 676 (Wells and Coppersmith, 1994). If the rupture breaches the $6 \mathrm{~km}$ wide Tianzhu 677 stepover and propagates to the western part of the Maomao Shan section, the rupture 678 length could reach $120 \mathrm{~km}$ and the maximum magnitude Mw 7.5 (Wells and 679 Coppersmith, 1994). Although breaching such stepovers may be difficult (e.g., 680 Wesnousky, 2006; Y1k1lmaz et al., 2015), cascading stepping ruptures are not unusual 681 (e.g., Tocheport et al., 2006; Xu et al., 2008; Hamling et al., 2017; Fletcher et al., 682 2014). Thus, the Jinqiang He and adjacent sections could be ripe for rupture in a 683 future great earthquake. Precise seismic risk assessment demands further detailed 684 paleoseismological investigations be carried out to define the rupture history along the 685 central Haiyuan fault. 
687

688

689

690

691

692

693

694

695

696

697

698

699

700

701

702

703

704

705

706

707

708

709

710

711

712

713

714

\section{CONCLUSION}

High resolution topography data derived from terrestrial LiDAR and Structure-from-Motion photogrammetry enable us to investigate in great detail of the offset features at the Daqing site along the Jinqiang He section of the Haiyuan fault. Terraces T1, T2', T2 and T3 were carefully mapped from field observations, orthophotos, and topographic data to produce a detailed geomorphic map of the site. Far- and near-field, top and base, of the various riser offsets have been measured as well as the vertical offset of the terraces. Horizontal offsets range from 6 to $97 \mathrm{~m}$, vertical offsets range from 1 to $17 \mathrm{~m}$. The smallest horizontal offset of $6.0 \pm 0.5 \mathrm{~m}$ may be associated with the most recent coseismic slip. Terrestrial cosmogenic nuclides dating combined with ${ }^{14} \mathrm{C}$ and OSL dating were used to constrain the age of the highest terrace T3 at $13.7 \pm 1.5 \mathrm{ka}$. Together with the total offset of terrace riser T3/T2 of $88 \pm 9 \mathrm{~m}$, it yields a left-lateral slip rate of $6.5 \pm 1 \mathrm{~mm} / \mathrm{yr}$. The offset of $72 \pm$ $5 \mathrm{~m}$ of the riser T3/T2 base, using the minimum age of the lower terrace $(9.3 \pm 0.6 \mathrm{ka})$, yields a rate of $7.7 \pm 0.6 \mathrm{~mm} / \mathrm{yr}$. Overall these bounds bracket a geologic slip rate of $5-8 \mathrm{~mm} / \mathrm{yr}$ for the Haiyuan fault that is consistent with the bounds estimated from geodetic data. Overall, compared to pre-existing geological rates, our rate falls in between the lower and higher estimates. At the Daqing site, the ratio of vertical and horizontal offsets of all terraces (about 1:5.2) is consistent with a uniform slip vector over time. The Daqing site provides an example that the right-bank terrace risers on a left-lateral fault, i.e., erosive side, are subject to incomplete riser refreshment and partial preservation of riser offsets.

\section{ACKNOWLEDGMENTS}

This work is jointly funded by the National Natural Science Foundation of China (41802228, U1839203), the Science for Earthquake Resilience of China Earthquake Administration (XH19044, XH18048), and YS has been partly supported by a grant from K.C. Wong Foundation and CNRS. YK is partly supported by China - France 
715 PICS program from CNRS. GF-1 satellite imagery was offered by Dr. Wang Lin from

716 Institute of Earthquake Science, China Earthquake Administration. We thank Alex

717 Morelan and Veronica Prush in UC Davis for their advice on sample ages analysis.

718 We are grateful to ASTER Team (G. Aumaître, D. Bourlès, and K. Keddadouche) at

719 ASTER-CEREGE for AMS measurements. This work was financially supported by

720 the INSU-CNRS, France and the University of Strasbourg to J. Van der Woerd for the

$721 \mathrm{Al}$ and Be concentration analyses at LHyGeS and IPGS, and for 10Be/9Be and

722 26Al/27Al ratios measurements on the Aster AMS facility (GEREGE,

723 Aix-en-Provence, France) supported by INSU-CNRS and IRD.

724 


\section{REFERENCES CITED}

Aitken, M. J., 1998, Introduction to optical dating: the dating of Quaternary sediments by the use of photon-stimulated luminescence. Clarendon Press.

Arrowsmith, J R., and Zielke O., 2009, Tectonic geomorphology of the San Andreas fault zone from High Resolution Topography: an example from the Cholame Section: Geomorphology, v. 113, p. 70-81, doi:10.1016/j.geomorph.2009.01.002.

Bemis, S. P., Micklethwaite, S., Turner, D., James, M. R., Akciz, S., Thiele, S. T., and Bangash, H. A., 2014, Ground-based and UAV-based photogrammetry: A multi-scale, high-resolution mapping tool for structural geology and paleoseismology: Journal of Structural Geology, v. 69, p. 163-178.

Benedetti, L.C. and Van Der Woerd, J., 2014, Cosmogenic nuclide dating of earthquakes, faults, and toppled blocks: Elements, v. 10, no. 5, p. 357-361.

Berryman, K., 1990, Late Quaternary movement on the Wellington fault in the Upper Hutt area, New Zealand: New Zealand journal of geology and geophysics, v. 33, no. 2, p. $257-270$.

Burchfiel, B.C., Quidong, D., Molnar, P., Royden, L., Yipeng, W., Peizhen, Z. and Weiqi, Z., 1989, Intracrustal detachment within zones of continental deformation: Geology, v. 17, no. 8, p. 748-752.

Carne, R.C., Little, T.A. and U Rieser, 2011, Using displaced river terraces to determine Late Quaternary slip rate for the central Wairarapa Fault at Waiohine River, New Zealand: New Zealand Journal of Geology and Geophysics, v.54, no. 2, p. 217-236, doi: 10.1080/00288306.2010.532224.

Carretier, S., Regard, V., Vassallo, R., Martinod, J., Christophoul, F., Gayer, E., Audin, L. and Lagane, C., 2015, A note on 10Be-derived mean erosion rates in catchments with heterogeneous lithology: Examples from the western Central Andes: Earth Surface Processes and Landforms, v. 40, no. 13, p. 1719-1729. 
Cavalié, O., Lasserre,C., Doin, M.-P., Peltzer, G., Sun, J., Xu, X., Shen, Z.-K., 2008, Measurement of interseismic strain across the Haiyuan fault (Gansu, China), by InSAR: Earth and Planetary Science Letters, doi:10.1016/j.eps1.07.057.

Chen, T., Zhang, P. Z., Liu J., Li, C. Y., Ren, Z. K., Hudnut, K. W., 2014, Quantitative study of tectonic geomorphology along Haiyuan fault based on airborne LiDAR: Chinese Science Bulletin, v. 59, no. 20, p. 2396-2409, doi:10.1007/s11434-014-0199-4.

Chen, T., Akciz, S.O., Hudnut, K.W., Zhang, D.Z. and Stock, J.M., 2015, Fault-Slip Distribution of the 1999 Mw 7.1 Hector Mine Earthquake, California, Estimated from Postearthquake Airborne LiDAR Data: Bulletin of the Seismological Society of America, v. 105, no. 2A, p. 776-790.

Chen, T., Liu-Zeng, J., Shao, Y., Zhang, P., Oskin, M.E., Lei, Q. and Li, Z., 2018. Geomorphic offsets along the creeping Laohu Shan section of the Haiyuan fault, northern Tibetan Plateau: Geosphere, v. 14, no. 3, p. 1165-1186.

Chevalier, M.L., Leloup, P.H., Replumaz, A., Pan, J., Liu, D., Li, H., Gourbet, L. and Métois, M., 2016, Tectonic-geomorphology of the Litang fault system, SE Tibetan Plateau, and implication for regional seismic hazard: Tectonophysics, v. 682, p. 278-292.

Chuang, R.Y. and Johnson, K.M., 2011, Reconciling geologic and geodetic model fault slip-rate discrepancies in Southern California: Consideration of nonsteady mantle flow and lower crustal fault creep. Geology, v. 39, no. 7, p. 627-630.

Clark, K., E. Nissen, J. Howarth, I. Hamling, J. Mountjoy, W. Ries, K. Jones, S. Goldstein, U. Cochran, P. Villamor, S. Hreinsdóttir, N. Litchfield, C. Mueller, K. Berryman, D. Strong. 2017, Highly variable coastal deformation in the $2016 \mathrm{Mw}$ 7.8 Kaikōura earthquake reflects rupture complexity along a transpressional plate boundary: Earth and Planetary Science Letters,474, p. 334-344.

Cowgill, E., 2007, Impact of riser reconstructions on estimation of secular variation in rates of strike-slip faulting: revisiting the Cherchen River site along the Altyn Tagh 
Fault, NW China: Earth and Planetary Science Letters, v. 254, p. 239-255, doi: 10.1016/j.eps1.2006.09.015.

Cowgill, E., Gold, R.D., Xuanhua, C., Xiao-Feng, W., Arrowsmith, J.R. and Southon, J., 2009, Low Quaternary slip rate reconciles geodetic and geologic rates along the Altyn Tagh fault, northwestern Tibet: Geology, v. 37, no. 7, p.647-650.

Daout, S., Jolivet, R., Lasserre, C., Doin, M.P., Barbot, S., Tapponnier, P., Peltzer, G., Socquet, A. and Sun, J., 2016, Along-strike variations of the partitioning of convergence across the Haiyuan fault system detected by InSAR: Geophysical Journal International, v. 205, p. 536-547, ,doi:10.1093/gji/ ggw028.

Deng, Q., Sung, F., Zhu, S., Li, M., Wang, T., Zhang, W., Burchfiel, B.C., Molnar, P. and Zhang, P., 1984, Active faulting and tectonics of the Ningxia-Hui autonomous region, China: Journal of Geophysical Research, v. 89, p. 4427-4445.

Duvall, A.R., Clark, M.K., Kirby, E., Farley, K.A., Craddock, W.H., Li, C. and Yuan, D.Y., 2013, Low-temperature thermochronometry along the Kunlun and Haiyuan Faults, NE Tibetan Plateau: Evidence for kinematic change during late-stage orogenesis: Tectonics, v. 32, no. 5, p. 1190-1211.

England, P. and Molnar, P., 1997, The field of crustal velocity in Asia calculated from Quaternary rates of slip on faults: Geophysical Journal International, v. 130, no. 3, p. 551-582.

Fletcher, J.M., et al., 2014, Assembly of a large earthquake from a complex fault system: surface rupture kinematics of the 4 April 2010 El Mayor-Cucapah (Mexico) Mw7.2 earthquake: Geosphere, v. 10, p. 797-827.

Galbraith, R.F. and Roberts, R.G., 2012, Statistical aspects of equivalent dose and error calculation and display in OSL dating: an overview and some recommendations: Quaternary Geochronology, v. 11, p. 1-27.

Gan, W., Zhang, P.Z., Shen, Z.-K., Niu, Z., Wang, M., Wan, Y., Zhou, D., Cheng, J., 2007, Present-day crustal motion within the Tibetan Plateau inferred from GPS 
measurements: Journal of Geophysical Research, v. 112, no. B8, doi:10.1029/2005JB004120.

Gaudemer, Y., Tapponnier, P. and Turcotte, D.L., 1989, River offsets across active

809 strike-slip faults: Ann. tecton., v. 3, no. 3, p. 55-76.

810 Gaudemer, Y., Tapponnier, P., Meyer, B., Peltzer, G., Guo Shunmin, Chen Zhitai,

811 Dai Huagung and Cifuentes, I., 1995, Partitioning of crustal slip between linked,

812 active faults in the eastern Qilianshan, and evidence for a major seismic gap, the

813 'Tianzhu gap', on the western Haiyuan fault, Gansu(China): Geophysical Journal

814 International, v. 120, p. 599-645.

815 Gold, R.D., Cowgill, E., Arrowsmith, J.R., Gosse, J., Chen, X., and Wang, X.- F., 8162009 , Riser diachroneity, lateral erosion, and uncertainty in rates of strike-slip 817 faulting: A case study from Tuzidun along the Altyn Tagh Fault, NW China: 818 Journal of Geophysical Research: Solid Earth, v. 114, no. B4, doi: $819 \quad 10.1029 / 2008 J B 005913$.

820 Gold, R.D., Cowgill, E., Arrowsmith, J.R., Chen, X., Sharp, W.D., Cooper, K.M. and 821 Wang, X.F., 2011a, Faulted terrace risers place new constraints on the late 822 Quaternary slip rate for the central Altyn Tagh fault, northwest Tibet. Geological 823 Society of America Bulletin, v. 123, no. 5-6, p. 958-978.

824 Gold, R.D. and Cowgill, E., 2011b, Deriving fault-slip histories to test for secular 825 variation in slip, with examples from the Kunlun and Awatere faults: Earth and 826 Planetary Science Letters, v. 301, no. 1-2, p. 52-64.

827 Gold, R.D., Cowgill, E., Arrowsmith, J.R. and Friedrich, A.M., 2017a, Pulsed strain 828 release on the Altyn Tagh fault, northwest China: Earth and Planetary Science 829 Letters, v. 459, p. 291-300.

830 Gold, R. D., Briggs, R. W., Crone, A. J., and DuRoss, C. B., 2017b, Refining fault 831 slip rates using multiple displaced terrace risers-An example from the Honey 832 Lake fault, NE California, USA: Earth and Planetary Science Letters, v. 477, p. $833 \quad 134-146$. 
834 Guo, P., Han, Z., Mao, Z., Xie, Z., Dong, S., Gao, F. and Gai, H., 2019,

835 Paleoearthquakes and rupture behavior of the Lenglongling fault: Implications for

836 seismic hazards of the northeastern margin of the Tibetan Plateau: Journal of

837 Geophysical Research: Solid Earth, doi: 10.1029/2018JB016586.

838 Hamling, I.J., et al., 2017, Complex multifault rupture during the 2016 Mw7.8

839 Kaikoura earthquake, New Zealand: Science, 10.1126/science.aam7194.

840 Harkins, N., and Kirby, E., 2008, Fluvial terrace riser degradation and determination 841 of slip rates on strike-slip faults: An example from the Kunlun fault, China: Geo842 physical Research Letters, v. 35, no. L05406, 6 p., doi: 10.1029/2007GL033073.

843 He, W.G., Liu, B.C., Yuan, D.Y., and Yang, M., 2000, Study on the slip rate of

844 Lenglongling active fault zone: Northwestern Seismological Journal, v. 22, no. 1, p. 845 90-97 (in Chinese).

846 He, W.G., Yuan, D.Y., Ge, W.P. and Luo, H., 2010, Determination of the slip rate of 847 the Lenglongling Fault in the middle and eastern segments of the Qilian Mountain 848 active fault zone: Earthquake, v. 30, no. 1, p. 131-137 (in Chinese).

849 Heimsath, A.M. and McGlynn, R., 2008, Quantifying periglacial erosion in the Nepal 850 high Himalaya: Geomorphology, v. 97, no. 1-2, p. 5-23.

851 Heyman, J., Stroeven, A.P., Harbor, J.M., Caffee, M.W., 2011, Too young or too old: 852 evaluating cosmogenic exposure dating based on an analysis of compiled boulder 853 exposure ages: Earth and Planetary Science Letters, v. 302, p. 71-80.

854 Hetzel, R., Tao, M., Stokes, S., Niedermann, S., Ivy-Ochs, S., Gao, B., Strecker, M.R. 855 and Kubik, P.W., 2004, Late Pleistocene/Holocene slip rate of the Zhangye thrust 856 (Qilian Shan, China) and implications for the active growth of the northeastern 857 Tibetan Plateau: Tectonics, v. 23, no. 6, doi: 10.1029/2004TC001653.

858 Hetzel, R., 2013, Active faulting, mountain growth, and erosion at the margins of the 859 Tibetan Plateau constrained by in situ-produced cosmogenic nuclides: 860 Tectonophysics, v. 582, p. 1-24. 
861 Hetzel, R., Hampel, A., Gebbeken, P., Xu, Q., \& Gold, R. D., 2019, A constant slip

862 rate for the western Qilian Shan frontal thrust during the last 200 ka consistent with

863 GPS-derived and geological shortening rates: Earth and Planetary Science Letters,

864 v. 509, p. $100-113$.

865 Hubert-Ferrari, A., Armijo, R., King, G., Meyer, B., and Barka, A., 2002,

866 Morphology, displacement, and slip rates along the North Anatolian Fault, Turkey:

867 Journal of Geophysical Research: Solid Earth, v. 107, no. B10, doi:

$868 \quad 10.1029 / 2001 J B 000393$.

869 Hudnut, K.W., Borsa, A., Glennie, C. and Minster, J.B., 2002, High-resolution

870 topography along surface rupture of the 16 October 1999 Hector Mine, California,

871 earthquake (Mw 7.1) from airborne laser swath mapping: Bulletin of the

872 Seismological Society of America,America, v. 92, no. 4, p. 1570-1576.

873 James, M.R., and Robson, S., 2012. Straightforward reconstruction of 3D surfaces

874 and topography with a camera: accuracy and geoscience application: Journal of

875 Geophysical Research: Earth Surface, v. 117, doi: 10.1029/2011JF002289.

876 Jiang, W., Han, Z., Guo, P., Zhang, J., Jiao, Q., Kang, S. and Tian, Y., 2017, Slip rate

877 and recurrence intervals of the east Lenglongling fault constrained by

878 morphotectonics: Tectonic implications for the northeastern Tibetan Plateau:

879 Lithosphere, v. 9, no. 3, p. 417-430.

880 Johnson, K.M., 2013, Slip rates and off-fault deformation in Southern California

881 inferred from GPS data and models. Journal of Geophysical Research: Solid Earth,

882 v. 118, no. 10, p. $5643-5664$.

883 Jolivet, R., Lasserre, C., Doin, M.P., Peltzer, G., Avouac, J.P., Sun, J. and Dailu, R., 884 2013, Spatio-temporal evolution of aseismic slip along the Haiyuan fault, China: 885 Implications for fault frictional properties: Earth and Planetary Science Letters, v. 886377, p. 23-33. 
887 Kirby, E., Harkins, N., Wang, E., Shi, X., Fan, C., and Burbank, D., 2007, Slip rate 888 gradients along the eastern Kunlun fault: Tectonics, v. 26, TC2010, 889 doi:10.1029/2006TC002033.

890 Klinger, Y., Etchebes, M., Tapponnier, P. and Narteau, C., 2011, Characteristic slip

891 for five great earthquakes along the Fuyun fault in China: Nature Geoscience, v. 4, 892 no. 6 , p. $389-392$.

893 Knuepfer, P.L., 1992, Temporal variations in latest Quaternary slip across the 894 Australian-Pacific plate boundary, northeastern South Island, New Zealand: 895 Tectonics, v. 11, no. 3, p. 449-464.

896 Küster, Y., Hetzel, R., Krbetschek, M. and Tao, M., 2006, Holocene loess 897 sedimentation along the Qilian Shan (China): significance for understanding the 898 processes and timing of loess deposition: Quaternary Science Reviews, v. 25, no. 1, 899 p. $114-125$.

900 Lal, D., 1991, Cosmic ray labeling of erosion surfaces: in situ nuclide production rates 901 and erosion models: Earth and Planetary Science Letters, v. 104, p. 424-439.

902 Langridge, R. M., Rowland, J., Villamor, P., Mountjoy, J., Townsend, D. B., Nissen, 903 E., Madugo, C., Ries, W. F., Gasston, C., Canva, A., Alexandra E. Hatem, A. E., 904 Hamling, I., 2018, Coseismic rupture and preliminary slip estimates for the 905 Papatea Fault and its role in the 2016 Mw 7.8 Kaikōura, New Zealand, Earthquake: 906 Bulletin of the Seismological Society of America, v. 108, no. 3B, p. 1596-1622.

907 Lasserre C. , Morel P.H. , Gaudemer Y. , Tapponnier P., Ryerson F.J., King G.C.P., 908 Mtivier F., Kasser M., Kashgariana M., Liu Baichi, Lu Taiyi, Yuan Daoyang, 1999, 909 Postglacial left slip rate and past occurrence of $M \geq 8$ earthquakes on the western 910 Haiyuan fault, Gansu, China: Journal of Geophysical Research,Research, v. 104, 911 no. B8, p. 17633-17651.

912 Lasserre C., Gaudemer Y., Tapponnier P., Me'riaux A.-S., Woerd J.Van der, Yuan 913 Daoyang, Ryerson F. J., Finkel R. C., and Caffee M.W., 2002, Fast late Pleistocene 
914 slip rate on the Lenglongling section of the Haiyuan fault, Qinghai, China: Journal 915 of Geophysical Research, v. 107, no. B11, p. 2276.

916 Le Béon, M., Klinger, Y., Mériaux, A.S., Al-Qaryouti, M., Finkel, R.C., Mayyas, O. 917 and Tapponnier, P., 2012, Quaternary morphotectonic mapping of the Wadi Araba 918 and implications for the tectonic activity of the southern Dead Sea fault: Tectonics, 919 v. 31, no. 5, doi:10.1029/2012TC003112.

920 Le Dortz, K., Meyer, B., Sébrier, M., Braucher, R., Nazari, H., Benedetti, L., Fattahi, 921 M., Bourlès, D., Foroutan, M., Siame, L. and Rashidi, A., 2011, Dating inset 922 terraces and offset fans along the Dehshir Fault (Iran) combining cosmogenic and 923 OSL methods: Geophysical Journal International, v. 185, no. 3, p. 1147-1174.

924 Lensen, G.J., 1964, The general case of progressive fault displacement of flights of 925 degradational terraces: New Zealand journal of geology and geophysics, v. 7, no. 4, 926 p. $864-870$.

927 Lensen, G.J., 1968, Analysis of progressive fault displacement during downcutting at 928 the Branch River terraces, South Island, New Zealand: Geological Society of 929 America Bulletin, v. 79, no. 5, p. 545-556.

930 Li, C., Zhang, P.Z., Yin, J. and Min, W., 2009, Late Quaternary left-lateral slip rate of 931 the Haiyuan fault, northeastern margin of the Tibetan Plateau: Tectonics, v. 28, no. $932 \quad$ 5, doi:10.1029/2008TC002302.

933 Liang, S.M., Zheng, W.J., Chen, G., 2018, Offset distribution and slip rate of the 934 Jinqianghe fault of the Qilian-Haiyuan fault zone: Annual meeting of Chinese 935 Geoscience Union, Abastract in Chinese.

936 Liu, J.R., Ren, Z.K., Zhang, H.P., Li, C.Y., Zhang, Z.Q., Zheng, W.J., Li, X.M., Liu, 937 C.C., 2018, Late Quaternary slip rate of the Laohushan fault within the Haiyuan 938 fault zone and its tectonic implications: Chinese Journal of Geophysics, v. 61, no. 939 4, p. 1281-1297, doi: 10.6038/cjg2018L0364 (in Chinese).

940 Liu-Zeng, J., Klinger, Y., Xu, X., Lasserre, C., Chen, G., Chen, W., Tapponnier, P. 941 and Zhang, B., 2007, Millennial recurrence of large earthquakes on the Haiyuan 
942 fault near Songshan, Gansu Province, China: Bulletin of the Seismological Society

943 of America, v. 97, no. 1B, p. 14-34.

944 Liu-Zeng, J., Chen T, Zhang P. Z., Zhang H. P., Zheng W. J., Ren Z K, Liang S. M.,

945 Shen C. S., Gan W.J., 2013, Illuminating the active Haiyuan fault, China by

946 AirborneLight Detection and Ranging: Chinese Science Bulletin, v. 58, p. 41-45, 947 doi: 10.1360/972012-1526 (in Chinese).

948 Liu-Zeng, J., Shao, Y., Klinger, Y., Xie, K., Yuan, D. and Lei, Z., 2015, Variability in 949 magnitude of paleoearthquakes revealed by trenching and historical records, along 950 the Haiyuan Fault, China: Journal of Geophysical Research: Solid Earth, v. 120, no. $951 \quad 12$, p. 8304-8333.

952 Lu, Y. C., Wang, X. L., and Wintle, A. G., 2007, A new OSL chronology for dust 953 accumulation in the last 130,000 yr for the Chinese Loess Plateau. Quaternary 954 Research, v. 67, no. 1, p. 152-160.

955 Matrau, R., Y. Klinger1, J. Van der Woerd, J. Liu-Zeng, Z. Li, X. Xu, and R. Zheng, 956 2019, Late Pleistocene-Holocene slip rate along the Hasi Shan restraining bend of 957 the Haiyuan fault: implication for faulting dynamics of a complex fault system: $958 \quad$ Tectonics, doi: 10.1029/2019TC005488.

959 Mason, D. P., Little, T. A., and Van Dissen, R. J., 2006, Rates of active faulting 960 during late Quaternary fluvial terrace formation at Saxton River, Awatere fault, 961 New Zealand: Geological Society of America Bulletin, v. 118, no. 11-12, p. 962 1431-1446.

963 McGill, S.F., Owen, L.A., Weldon, R.J. and Kendrick, K.J., 2013, Latest Pleistocene 964 and Holocene slip rate for the San Bernardino strand of the San Andreas fault, 965 Plunge Creek, Southern California: Implications for strain partitioning within the 966 southern San Andreas fault system for the last 35 ky: Geological Society of 967 America Bulletin, v. 125, no. 1-2, p. 48-72.

968 Meade, B.J., Klinger, Y. and Hetland, E.A., 2013, Inference of multiple earthquake969 cycle relaxation timescales from irregular geodetic sampling of interseismic 
970

971

972

973

974

975

976

977

978

979

980

981

982

983

984

985

986

987

988

989

990

991

992

993

994

995

996

deformation: Bulletin of the Seismological Society of America, v. 103, no. 5, p. $2824-2835$

Mériaux, A.-S., Ryerson, F.J., Tapponnier, P., Van der Woerd, J., Finkel, R.C., Xu, X., Xu, Z., and Caffee, M.W., 2004, Rapid slip along the central Altyn Tagh fault: Morphochronologic evidence from Cherchen He and Sulamu Tagh: Journal of Geophysical Research, v. 109, B06401, doi: 10/1029/2003jb002558.

Mériaux, A.S., Tapponnier, P., Ryerson, F.J., Xu, X.W., King, G., Van der Woerd, J., Finkel, R.C., Li, H.B., Caffee, M.W., Xu, Z.Q., Chen, W.B., 2005, The Aksay section of the northern Altyn Tagh fault: tectonic geomorphology, landscape evolution, and Holocene slip rate: Journal of Geophysical Research: Solid Earth, v. 110, no. B4, B04404.

Mériaux, A.S., Van Der Woerd, J., Tapponnier, P., Ryerson, F.J., Finkel, R.C., Lasserre, C. and Xu, X., 2012. The Pingding segment of the Altyn Tagh Fault (91 ${ }^{\circ}$ E): Holocene slip-rate determination from cosmogenic radionuclide dating of offset fluvial terraces: Journal of Geophysical Research: Solid Earth, v. 117, no. B9.

Meyer, B., Tapponnier, P., Gaudemer, Y., Peltzer, G., Guo, S., Chen, Z., 1996, Rate of left-lateral movement along the easternmost segment of the Altyn Tagh Fault, east of $96^{\circ} \mathrm{E}$ (China): Geophysical Journal International, v. 124, p. 29-44.

Meyer, B., Tapponnier, P., Bourjot, L., Metivier, F., Gaudemer, Y., Peltzer, G., Shunmin, G. and Zhitai, C., 1998, Crustal thickening in Gansu-Qinghai, lithospheric mantle subduction, and oblique, strike-slip controlled growth of the Tibet plateau: Geophysical Journal International, v. 135, no. 1, p. 1-47.

Middleton, T.A., Walker, R.T., Parsons, B., Lei, Q., Zhou, Y. and Ren, Z., 2016, A major, intraplate, normal-faulting earthquake: The 1739 Yinchuan event in northern China: Journal of Geophysical Research: Solid Earth., v. 121, no. 1, p. 293-320. 
997 Min, W., P. Zhang, Q. Deng, and F. Mao, 2001, Detailed study of Holocene

998 paleoearthquakes of the Haiyuan active fault: Geology Review v. 47, no. 1, p. 7599981.

1000 Oskin, M. E., K. Le, and M. D. Strane, 2007, Quantifying fault-zone activity in arid 1001 environments with high-resolution topography: Geophysical Research Letters, v. 1002 34, no. L23S05, doi:10.1029/2007GL031295.

1003 Oskin, M.E., Arrowsmith, J.R., Corona, A.H., Elliott, A.J., Fletcher, J.M., Fielding, 1004 E.J., Gold, P.O., Garcia, J.J.G., Hudnut, K.W., Liu-Zeng, J. and Teran, O.J., 2012, 1005 Near-field deformation from the El Mayor-Cucapah earthquake revealed by 1006 differential LiDAR: Science, v.335, no. 6069, p. 702-705.

1007 Owen, L.A., Spencer, J.Q., Ma Haizhou, Barnard, P.L., Derbyshire, E., Finkel, R.C., 1008 Caffee, M.W. and Zeng Yong Nian, 2003, Timing of Late Quaternary glaciation 1009 along the southwestern slopes of the Qilian Shan. Boreas, v. 32, p. 281-291.

1010 Owen, L.A., Frankel, K.L., Knott, J.R., Reynhout, S., Finkel, R.C., Dolan, J.F. and 1011 Lee, J., 2011, Beryllium-10 terrestrial cosmogenic nuclide surface exposure dating 1012 of Quaternary landforms in Death Valley: Geomorphology, v. 125, no. 4, p. $1013 \quad 541-557$.

1014 Papanikolaou, I.D., Roberts, G.P. and Michetti, A.M., 2005, Fault scarps and 1015 deformation rates in Lazio-Abruzzo, Central Italy: Comparison between 1016 geological fault slip-rate and GPS data. Tectonophysics, v. 408, no. 1-4, p. 1017 147-176.

1018 Peltzer, G., Tapponnier, P., Gaudemer, Y., Meyer, B., Guo, S., Yin, K., Chen, Z. and 1019 Dai, H., 1988, Offsets of late Quaternary morphology, rate of slip, and recurrence 1020 of large earthquakes on the Chang Ma fault (Gansu, China): Journal of 1021 Geophysical Research: Solid Earth, v. 93, no. B7, p. 7793-7812.

1022 Peltzer, G., Brown, N.D., Mériaux, A.S.B., Van der Woerd, J., Rhodes, E.J., Finkel, 1023 R.C., Ryerson, F.J. and Hollingsworth, J., 2020, Stable rate of slip along the 1024 Karakax section of the Altyn Tagh Fault from observation of inter-glacial and post- 
1025 glacial offset morphology and surface dating: Journal of Geophysical Research:

1026 Solid Earth, doi: 10.1029/2019JB018893.

1027 Peltzer, G., Tapponnier, P. and Armijo, R., 1989, Magnitude of late Quaternary

1028 left-lateral displacements along the north edge of Tibet: Science, v. 246, no. 4935,

1029 p. $1285-1289$.

1030 Perrineau, A., Van Der Woerd, J., Gaudemer, Y., Liu-Zeng, J., Pik, R., Tapponnier, P.,

1031 Thuizat, R. and Rongzhang, Z., 2011, Incision rate of the Yellow River in

1032 Northeastern Tibet constrained by $10 \mathrm{Be}$ and $26 \mathrm{Al}$ cosmogenic isotope dating of

1033 fluvial terraces: implications for catchment evolution and plateau building:

1034 Geological Society, London, Special Publications, v. 353, no. 1, p. 189-219.

1035 Prush, V., and Oskin, M., 2020, A mechanistic erosion model for cosmogenic

1036 inheritance in single-clast exposure ages, Earth and Planetary Science Letters, v.

$1037 \quad$ 535, doi:10.1016/j.epsl.2020.116066.

1038 Putkonen, J. and Swanson, T., 2003, Accuracy of cosmogenic ages for moraines:

1039 Quaternary Research, v. 59, no. 2, p. 255-261.

1040 Ran, Y., R. Duan, and Q. Deng, 1997, 3-D trench excavation and paleoseismology at

1041 Gaowanzi of the Haiyuan Fault: Earthquake Geology, v. 19, no. 2, p. 97-107(in

1042 Chinese with English abstract).

1043 Reitman, N.G., Mueller, K.J., Tucker, G.E., Gold, R.D., Briggs, R.W. and Barnhart,

1044 K.R., 2019. Offset channels may not accurately record strike - slip fault

1045 displacement: Evidence from landscape evolution models: Journal of Geophysical

1046 Research: Solid Earth, doi: 10.1029/2019JB018596

1047 Ren, Z., Zhang, Z., Chen, T., Yan, S., Yin, J., Zhang, P., Zheng, W., Zhang, H. and Li,

1048 C., 2016. Clustering of offsets on the Haiyuan fault and their relationship to 1049 paleoearthquakes: Geological Society of America Bulletin, v. 128, no. 1-2, p. 3-18.

1050 Ritz, J.-F., R. Vassallo, R. Braucher, E.T. Brown, S. Carretier, D.L. Bourlès, 2006,

1051 Using in situ-produced ${ }^{10} \mathrm{Be}$ to quantify active tectonics in the Gurvan Bogd 
1052

1053

1054

1055

1056

1057

1058

1059

1060

1061

1062

1063

1064

1065

1066

1067

1068

1069

1070

1071

1072

1073

1074

1075

1076

1077

1078

1079

mountain range (Gobi-Altay, Mongolia):): Geological Society of America Special Paper, v. 415, p. 87-110.

Rizza, M., Ritz, J. F., Braucher, R., Vassallo, R., Prentice, C., Mahan, S., S. McGill, A. Chauvet, S. Marco, M. Todbileg, S. Demberel and D. Bourles, 2011, Slip rate and slip magnitudes of past earthquakes along the Bogd left-lateral strike-slip fault (Mongolia): Geophysical Journal International, v. 186, no. 3, p. 897-927.

Rodgers, D.W. and Little, T.A., 2006, World's largest coseismic strike-slip offset: The 1855 rupture of the Wairarapa Fault, New Zealand, and implications for displacement/length scaling of continental earthquakes: Journal of Geophysical Research: Solid Earth, v. 111, no. B12, doi: 10.1029/2005JB004065.

Ryerson, F.J., Tapponnier, P., Finkel, R.C., Meriaux, A., Van der Woerd, J., Lasserre, C., Chevalier, M., Xu, X.W., Li, H.B. and King, G.C., 2006, Applications of morphochronology to the active tectonics of Tibet: Geological Society Of America Special Paper, v. 415, p. 61.

Sieh, K.E., 1981, A review of geological evidence for recurrence times of large earthquakes (No. 4, p. 181-207). Washington, DC: American Geophysical Union.

Sieh, K.E. and Jahns, R.H., 1984, Holocene activity of the San Andreas fault at Wallace creek, California: Geological Society of America Bulletin, v. 95, no. 8, p. 883-896.

Stewart, N., Gaudemer, Y., Manighetti, I., Serreau, L., Vincendeau, A., Dominguez, S., L. Mattéo, J. Malavieille, 2018, “3D_Fault_Offsets,” a Matlab code to automatically measure lateral and vertical fault offsets in topographic data: Application to San Andreas, Owens Valley, and Hope faults: Journal of Geophysical Research: Solid Earth, v. 123, p. 815-835. doi:10.1002/2017JB014863.

Stokes, S., Hetzel, R., Bailey, R.M. and Mingxin, T., 2003, Combined IRSL-OSL single aliquot regeneration (SAR) equivalent dose (De) estimates from source proximal Chinese loess: Quaternary Science Reviews, v. 22, no. 10, p. 975-983. 
1080 Stone, J.O., 2000, Air pressure and cosmogenic isotope production: Journal of 1081 Geophysical Research, v. 105, p. 23753-23759.

1082 Stuiver M. and P.J. Reimer, 1993, Extended 14C data base and revised CALIB 3.0

1083 14C Age calibration program: Radiocarbon, v. 35, no. 1, p. 215-230.

1084 Tapponnier, P. and Molnar, P., 1977, Active faulting and tectonics in China: Journal 1085 of Geophysical Research, v. 82, no. 20, p. 2905-2930.

1086 Tapponnier, P., Meyer, B., Avouac, J.P., Peltzer, G., Gaudemer, Y., Shunmin, G., 1087 Hongfa, X., Kelun, Y., Zhitai, C., Shuahua, C. and Huagang, D., 1990, Active 1088 thrusting and folding in the Qilian Shan, and decoupling between upper crust and 1089 mantle in northeastern Tibet: Earth and Planetary Science Letters, v. 97, no. 3-4, p. $1090 \quad 382-403$.

1091 Tapponnier, P., Zhiqin, X., Roger, F., Meyer, B., Arnaud, N., Wittlinger, G. and 1092 Jingsui, Y., 2001a, Oblique stepwise rise and growth of the Tibet Plateau: Science, 1093 v. 294 , no. 5547 , p. $1671-1677$.

1094 Tapponnier, P., Ryerson, F.J., Van Der Woerd, J., Mériaux, A.S. and Lasserre, C., 1095 2001b, Long-term slip rates and characteristic slip: keys to active fault behaviour 1096 and earthquake hazard: Comptes Rendus de l'Académie des Sciences-Series 1097 IIA-Earth and Planetary Science, v. 333, no. 9, p. 483-494.

1098 Thackray, G.D., Rodgers, D.W. and Streutker, D., 2013, Holocene scarp on the 1099 Sawtooth fault, central Idaho, USA, documented through lidar topographic 1100 analysis: Geology, v. 41, no. 6, p. 639-642.

1101 Tocheport, A., Rivera, L., and Van der Woerd, J., 2006, A study of the 14 November 11022001 Kokoxili earthquake: History and geometry of the rupture from teleseismic 1103 data and field observations: Bulletin of the Seismological Society of America, v. 110496 , no. 5, p. 1729-1741.

1105 Tong, X., Smith-Konter, B. and Sandwell, D.T., 2014, Is there a discrepancy between 1106 geological and geodetic slip rates along the San Andreas Fault System?: Journal of 1107 Geophysical Research: Solid Earth, v. 119, no. 3, p. 2518-2538. 
1108 Van der Woerd J., F.J. Ryerson, P. Tapponnier, Y. Gaudemer, R. Finkel, A. S. 1109 Mériaux, M. Caffee, Zhao Guoguang, He Qunlu, 1998, Holocene left-slip rate 1110 determined by cosmogenic surface dating on the Xidatan section of the Kunlun 1111 Fault (Qinghai, China): Geology, v. 26, p. 695-698.

1112 Van Der Woerd, J., Ryerson, F.J., Tapponnier, P., Meriaux, A.S., Gaudemer, Y., 1113 Meyer, B., Finkel, R.C., Caffee, M.W., Guoguang, Z. and Zhiqin, X., 2000, 1114 Uniform slip-rate along the Kunlun fault: Implications for seismic behaviour and 1115 large-scale tectonics: Geophysical Research Letters, v. 27, no. 16, p. 2353-2356.

1116 Van der Woerd, J., Tapponnier, P., J. Ryerson, F., Meriaux, A.S., Meyer, B., 1117 Gaudemer, Y., Finkel, R.C., Caffee, M.W., Guoguan, Z. and Zhiqin, X., 2002, 1118 Uniform postglacial slip-rate along the central $600 \mathrm{~km}$ of the Kunlun Fault (Tibet), 1119 from $26 \mathrm{Al}, 10 \mathrm{Be}$, and $14 \mathrm{C}$ dating of riser offsets, and climatic origin of the 1120 regional morphology: Geophysical Journal International, v. 148, no. 3, p. 356-388. 1121 Van der Woerd, J., Y. Klinger, K. Sieh, P. Tapponnier, F.J. Ryerson, and A.-S. 1122 Mériaux, 2006, Long-term slip rate of the southern San Andreas Fault from 1123 10Be-26Al surface exposure dating of an offset alluvial fan: Journal of 1124 Geophysical Research, v. 111, no. B04407, doi:10.1029/2004JB003559.

1125 Wang, X., Vandenberghe, D., Yi, S., Vandenberghe, J., Lu, H., Van Balen, R., and 1126 Van den Haute, P., 2013, Late Quaternary paleoclimatic and geomorphological 1127 evolution at the interface between the Menyuan basin and the Qilian Mountains, 1128 northeastern Tibetan Plateau: Quaternary Research, v. 80, no. 3, p. 534-544.

1129 Weldon, R. J., and K. E. Sieh, 1985, Holocene rate of slip and tentative recurrence 1130 interval for large earthquakes on the San-Andreas Fault, Cajon-Pass, 1131 Southern-California: Geological Society of America Bulletin, v. 96, p. 793-812.

1132 Weldon, R., 1986, The late Cenozoic geology of Cajon Pass: Implications for 1133 tectonics and sedimentation along the San Andreas fault [Ph. D. thesis]. Pasadena, 1134 California Institute of Technology. 
1135 Weldon, R., Scharer, K., Fumal, T. and Biasi, G., 2004, Wrightwood and the

1136 earthquake cycle: What a long recurrence record tells us about how faults work:

1137 GSA today, v. 14, no. 9, p. 4-10.

1138 Wells, D., and K. Coppersmith, 1994, New empirical relationships among magnitude,

1139 rupture length, rupture width, rupture area, and surface displacement: Bulletin of 1140 the Seismological Society of America, v. 84, no. 4, p. 974-1002.

1141 Wesnousky, S. G., 2006, Predicting the endpoints of earthquake ruptures. Nature, v. 11424 444, no. 7117 , p. 358-360.

1143 Wu, G.J., Pan, B.T., Guan, Q.Y., Wang, J.M., Zhao, Z.J., 1998, Climatic changes in 1144 the north piedmont of eastern Qilian mountains since 10 ka B. P.: Journal of Desert 1145 Research, v. 18, no. 3, p. 1993-200 (in Chinese with English abstract)

1146 Xiang, H.F., Guo, S.M., Zhang, B.L., Zhang, W.X, Yasutaka, I., and He, H.L., 1998, 1147 Active features of the eastern Liupanshan piedmont reverse fault zone since late 1148 Quaternary: Seismology and Geology, v. 20, no. 4, p. 321-327(in Chinese).

1149 Xu, X., Yu, G., Ma, W., Klinger, Y., and Tapponnier, P., 2008, Rupture behavior and 1150 deformation localization of the Kunlunshan earthquake (Mw 7.8) and their tectonic 1151 implications: Science in China Series D: Earth Sciences, v. 51, no. 10, p. $1152 \quad$ 1361-1374.

1153 Yao, W.Q., Liu-Zeng, J., Oskin, M.E., Wang, W., Li, Z.F., Prush, V., Zhang, J.Y., 1154 Tang, M.Y., Shao, Y.X., Yuan, Z.D., Han, L.F., and Klinger, Y., 2019, 1155 Re-evaluation of the Late Pleistocene slip rate of the Haiyuan fault near Songshan, 1156 Gansu province, China: Journal of Geophysical Research: Solid Earth, v. 124, no. $1157 \quad 5$, p. 5217-40.

1158 Y1kılmaz, M. B., Turcotte, D. L., Heien, E. M., Kellogg, L. H., and Rundle, J. B., 11592015 , Critical jump distance for propagating earthquake ruptures across step-overs:

$1160 \quad$ Pure and Applied Geophysics, v. 172, no. 8, p. 2195-2201. 
1161 Yuan, D.Y., Liu, B.C., Lv, T.Y., He, W.G., and Liu, X.F., 1997, Palaeoearthquake

1162 features along the eastern segment of north Qilianshan active fault zone: South 1163 China Journal of Seismology, v. 17, no. 2, p. 24-31 (in Chinese).

1164 Yuan, D.Y., Liu, B.C., Lv, T.Y., He, W.G., Liu, X.F., and Gan, W.J., 1998, Study on 1165 the sectionation of the eastern section of north Qilianshan active fault zone: 1166 Northwestern Seismological Journal, v. 20, no. 4, p. 27-34(in Chinese).

1167 Zhang, J., Nottebaum, V., Tsukamoto, S., Lehmkuhl, F. and Frechen, M., 2015, Late 1168 Pleistocene and Holocene loess sedimentation in central and western Qilian Shan 1169 (China) revealed by OSL dating. Quaternary International, v. 372, p. 120-129.

1170 Zhang P., Molnar, P., Burchfiel, B. C., Royden, L., Wang, Y., Deng, Q., Song, F., 1171 Zhang, W., and Jiao D., 1988a, Bounds on the Holocene slip rate along the 1172 Haiyuan fault, north-central China: Quaternary Research, v. 30, p. 151-164.

1173 Zhang P., Molnar, P., Weigi, Z., Qidong, D., Yipeng, W., Burchfiel, B.C., Fangmin, 1174 S., Royden, L. and Decheng, J., 1988b, Bounds on the average recurrence interval 1175 of major earthquakes along the Haiyuan fault in north-central China: Seismological 1176 Research Letters, v. 59, no. 3, p. 81-89.

1177 Zhang, P., W. Min, Q. Deng, and F. Mao, 2003, Paleoearthquake rupture behavior 1178 and recurrence of great earthquakes along the Haiyuan Fault, northwestern China: 1179 Science China, Ser. D, v. 46, p. 705-713.

1180 Zhang, P. Z., P. Molnar, and X. Xu, 2007, Late Quaternary and present-day rates of 1181 slip along the Altyn Tagh Fault, northern margin of the Tibetan Plateau: Tectonics, 1182 v. 26, no. TC5010, doi:10.1029/2006TC002014.

1183 Zheng, D. W., P. Z. Zhang, J. L. Wan, D. Y. Yuan, C. Y. Li, G. M. Yin, G. L. Zhang, 1184 Z. C. Wang, M. Min, and J. Chen, 2006, Rapid exhumation at similar to 8 Ma on 1185 the Liupan Shan thrust fault from apatite fission-track thermochronology: 1186 Implications for growth of the north- eastern Tibetan Plateau margin: Earth and 1187 Planetary Science Letters, v. 248, no. 1-2, p. 198-208. 
1188 Zheng, W.J., Zhang, P.Z., He, W.G., Yuan, D.Y., Shao, Y.X., Zheng, D.W., Ge, W.P.

1189 and Min, W., 2013, Transformation of displacement between strike-slip and crustal

1190 shortening in the northern margin of the Tibetan Plateau: Evidence from decadal

1191 GPS measurements and late Quaternary slip rates on faults: Tectonophysics, v. 584,

1192 p. 267-280.

1193 Zielke, O., J R. Arrowsmith, L. B. Grant-Ludwig, and S. O. Akciz, 2010, Slip in the

11941857 and earlier large earthquakes along the Carrizo section, San Andreas Fault:

1195 Science, v. 327, p. 1119-1122, doi:10.1126/science.1182781.

1196 Zielke, O., J R. Arrowsmith, L. B. Grant-Ludwig, and S. O. Akciz, 2012, High

1197 resolution topography-derived offset along the 1857 Fort Tejon earthquake rupture

1198 trace, San Andreas Fault: Bulletin of the Seismological Society of America, v. 102,

1199 no. 3, doi:10.1785/0120110230.

1200 Zielke, O., Klinger, Y. and Arrowsmith, J.R., 2015, Fault slip and earthquake

1201 recurrence along strike-slip faults - Contributions of high-resolution geomorphic

1202 data: Tectonophysics, v. 638, p. 43-62.

1203 Zinke, R., Dolan, J.F., Van Dissen, R., Grenader, J.R., Rhodes, E.J., McGuire, C.P.,

1204 Langridge, R.M., Nicol, A. and Hatem, A.E., 2015, Evolution and progressive 1205 geomorphic manifestation of surface faulting: A comparison of the Wairau and 1206 Awatere faults: South Island, New Zealand. Geology, v. 43, no. 11, p. 1019-1022.

1207 Zinke, R., Dolan, J. F., Rhodes, E. J., Van Dissen, R., \& McGuire, C. P., 2017, Highly

1208 variable latest Pleistocene-Holocene incremental slip rates on the Awatere fault at 1209 Saxton River, South Island, New Zealand, revealed by lidar mapping and 1210 luminescence dating: Geophysical Research Letters, v. 44, p. 11,301-11,310, doi: $1211 \quad$ 10.1002/2017GL075048.

1212

1213

1214 


\section{Figures caption:}

Figure 1. (A) Active faults map of northeastern Tibetan plateau. Seismicity from 780 $\mathrm{BC}$ to 2006 AD. Historical earthquakes from Division of Earthquake Monitoring and Prediction, State Seismologic Bureau (1995), instrumental seismicity from China Earthquake Networks Center (http://www.cenc.ac.cn/). White star indicates study site, dashed box is figure 1B. Haiyuan fault is subdivided into six sections separated by black arrows, from west to east: (1) Halahu, (2) Lenglong Ling, (3) Jinqiang He, (4) Maomao Shan, (5) Jingtai, (6) Haiyuan, and (7) Liupan Shan. Inset is location map showing tectonic framework of the Tibetan plateau.plateau (B) Active faults along Jinqiang He section that extends from Lenglong Ling-Gulang-Jinqiang (LGH) fault triple junction to the west, to Tianzhu pull-apart basin (TB) to the east, left-stepping to Maomao Shan section. Upper Jinqiang He valley is fed mostly by north-south tributaries flowing down from Leigong Shan to the north and crossing the Haiyuan fault at high angle. LLL: Lenglong Ling.

Figure 2. GF-1 satellite imagery (pixel $\sim 2 \mathrm{~m}$ ) of Jinqiang He section of Haiyuan fault near Daqing site (white rectangle) upstream from Honggeda village. Light shading delimits Tianzhu half pull-apart basin.

Figure 3. (A) Uncrewed aerial vehicle (UAV) derived photo mosaic with $\sim 0.2 \mathrm{~m}$ resolution of Daqing site. Fault trace is clear across stream bed T0 and terraces T1 to T3 to the west. Red arrows point to fault trace. (B) West-looking panoramic field view of faulted terraces at Daqing site. (C) Oblique close-up view showing fault trace across $\mathrm{T} 0, \mathrm{~T} 1$ and $\mathrm{T} 2$.

Figure 4. (A) Geomorphic map of Daqing site from field observations, UAV photo mosaic interpretation, and high-resolution DEM analysis. Contours with $1 \mathrm{~m}$ interval derived from $\sim 0.1 \mathrm{~m}$ resolution terrestrial LiDAR DEM. Dashed lines are topographic profiles shown in Figure 5. Pit and sample position for dating are indicated. Purple lines are terrace riser piercing lines for horizontal offset measurements. (B) Hill shading and (C) slope map of DEM highlighting terrace surface morphology, distinct terrace risers and fault scarp.

Figure 5. Topographic profiles across and along terraces at Daqing site. Locations shown in Figure 4. Gray dots are measurement points, solid black lines along slopes are fitting lines. AA', BB' and CC' are field GPS-RTK profiles, others are swath profiles extracted from LiDAR-DEM. Dashed line in swath profiles represents mean elevation value. Small sketch illustrates correction applied to apparent vertical offset of T3 due to oblique orientation of its sloping surface. Vr, corrected vertical offset, is function of Vi vertical throw measurement from perpendicular fault profile $\mathrm{C} 1-\mathrm{C} 1$ ', $\mathrm{h}$ 
is horizontal offset of terrace, $\alpha$ is angle of terrace slope parallel to fault (in profiles E1, E2, E3) (see also Gaudemer et al., 1995).

Figure 6. Field photographs of surface boulders sampled for cosmogenic dating from terraces T2 (A) and T1 (B). See position in Figure 4 and analytical details in Table 3.

Figure 7. (A) Field view of samplings pit in terrace T3 (position in Figure 4). (B) Stratigraphic description of pit. Eight gravels and pebbles samples were collected from below $80 \mathrm{~cm}$ to $3 \mathrm{~m}$ depth for cosmogenic isotope dating (details in Table 3). Open circles are sandy loess samples collected for OSL dating (Table 2), solid triangles are bulk soil samples for ${ }^{14} \mathrm{C}$ dating (Table 1).

Figure 8. Equivalent dose (De) distributions, natural OSL decay curve and growth curves for samples HGDOSL-1501 (A and B) and HGDOSL-1502 (C and D), respectively.

Figure 9. Offset terrace reconstructions. (A)-(E) diagrams of different stages during river downcutting, lateral erosion and displacement accumulation. Simplified risers are vertical. (F) sketch of offset terraces at Daqing site. All measurement results are shown in Table 4. (G) shows how near-field (d3t, d3b, d2t and d2b) and far-field displacements are related.

Figure 10. Field details of smalls stream offset on terrace T1. Red arrows indicate top of fault scarp across $\mathrm{T} 1$.

Figure 11. Ratio of vertical to horizontal offsets. Average ratio is $0.191+/-0.018$ by T3, $\mathrm{T} 2, \mathrm{~T} 2$ ' and $\mathrm{T} 1$.

Figure 12. Exposure age constraints at Daqing site. (A), (B) and (C) are proposed stepwise evolution of deposit for terrace T3 ${ }^{10} \mathrm{Be}$ depth profile modeling in (D), (E) and $(F) . t_{1-1}, t_{2-1}$ and $t_{3-1}$ are corresponding terrace abandonment ages for models 1,2 and 3; R-squared is statistical assessment of ${ }^{10} \mathrm{Be}$ data with respect to best fit, without outliers (black circles). Integrated density (blue line) and average inheritance indicated. (A and D) model 1: assumes all layers deposited in one step (I). (B and E) model 2: exposure in three steps: (I) terrace conglomerate only $\left(t_{2-1}-t_{2-2}\right)$, (II) with 30 $\mathrm{cm}$-thick sandy-loess $\left(\mathrm{t}_{2-2}-\mathrm{t}_{2-3}\right)$, and (III) with $80 \mathrm{~cm}$-thick soil $\left(\mathrm{t}_{2-3}-0\right)$. All layers are deposited instantaneously. ( $\mathrm{C}$ and F) model 3: same as model 2 but layers are deposited progressively, as constrained by OSL and ${ }^{14} \mathrm{C}$ dates. $(\mathrm{G}){ }^{10} \mathrm{Be}$ concentrations of surface samples from terraces T1 $(n=6)$ and T2 $(n=7))$ represented as Gaussian distributions. Scatter of distributions mostly attributed to inheritance (see 
text). Samples in bold (HGD14-23 and HGD14-27) are samples with lowest ${ }^{10} \mathrm{Be}$ concentration in each distribution.

Figure 13. Summary of terrace offsets at Daqing He site as a function of age. Solid rectangle is best determined rate from terrace T3. Dashed rectangles are less well determined. Gray shaded area is preferred range of the slip rate. 
TABLE 1. Radiocarbon analytical results of samples from terraces T3 and T2.

\begin{tabular}{|c|c|c|c|c|c|c|c|c|c|}
\hline Sample & $\mathrm{Lab}^{\mathrm{a}}$ & $\begin{array}{l}\text { Depth } \\
\text { (m) }\end{array}$ & $\begin{array}{l}\text { Fraction } \\
\text { Modern }\end{array}$ & \pm & $\begin{array}{c}\mathrm{D}^{14} \mathrm{C} \\
(\%)\end{array}$ & \pm & $\begin{array}{l}{ }^{14} \mathrm{C} \text { Age } \\
\text { (B.P.) }\end{array}$ & \pm & $\begin{array}{c}2 \sigma \text { calibrated age } \\
{\text { (B.P. })^{b}}^{\text {b }}\end{array}$ \\
\hline HGD-C14-01 & 414950 & 0.77 & 0.4236 & 0.0016 & -576.4 & 1.6 & 6900 & 30 & Cal $7790-7675$ \\
\hline HGD-C14-02 & 414951 & 0.62 & 0.4414 & 0.0016 & -558.6 & 1.6 & 6570 & 30 & Cal $7555-7545$ \\
\hline $\mathrm{L}-01^{\mathrm{c}}$ & & 0.89 & & & & & 8630 & 90 & Cal 9900 - 9474 \\
\hline $\mathrm{L}-02^{\mathrm{c}}$ & & 0.82 & & & & & 8180 & 140 & Cal $9475-8715$ \\
\hline
\end{tabular}

a: All samples were AMS dated at Beta Analytic;

b: Calibration with Calib 7.1 (Stuiver et al., 1993), did not include probability distribution of range $<0.1$;

c: L-01, L-02 are from Liang et al. (2018), Fraction Modern and $\mathrm{D}^{14} \mathrm{C}$ information not known.

TABLE 2. Analytical results of OSL samples from terrace T3.

\begin{tabular}{|c|c|c|c|c|c|c|c|c|c|c|c|}
\hline $\begin{array}{l}\text { Sample } \\
\text { No }\end{array}$ & $\begin{array}{l}\text { Lab. } \\
\text { no }^{\mathrm{a}}\end{array}$ & $\begin{array}{l}\text { Depth } \\
\text { (m) }\end{array}$ & $\begin{array}{c}\text { Water } \\
\text { content }^{\mathrm{b}} \\
(\%) \\
\end{array}$ & $\begin{array}{c}\mathrm{U} \\
(\mathrm{ppm})\end{array}$ & $\begin{array}{c}\text { Th } \\
\text { (ppm) }\end{array}$ & $\begin{array}{l}\mathrm{K} \\
(\%)\end{array}$ & $\begin{array}{c}\text { Cosmic dose } \\
\text { rate } \\
(\mathrm{Gy} / \mathrm{ka}) \\
\end{array}$ & $\begin{array}{l}\text { Grain size } \\
\qquad(\mu \mathrm{m})\end{array}$ & $\begin{array}{c}\text { Dose rate }^{\mathrm{c}} \\
(\mathrm{Gy} / \mathrm{ka})\end{array}$ & $\begin{array}{c}\text { Equivalent } \\
\text { dose }^{\mathrm{d}} \\
(\mathrm{Gy})\end{array}$ & $\begin{array}{r}\mathrm{Age}^{\mathrm{e}} \\
(\mathrm{ka}) \\
\end{array}$ \\
\hline HGDOSL-1502 & $15-64$ & 0.82 & 2.6 & $2.71 \pm 0.1$ & $14.4 \pm 0.392$ & $2.18 \pm 0.06$ & $0.32 \pm 0.02$ & $90-125$ & $4.06 \pm 0.15$ & $35.3 \pm 1.3$ & $8.7 \pm 0.5$ \\
\hline HGDOSL-1501 & $15-63$ & 1.04 & 8.04 & $2.45 \pm 0.1$ & $12.8 \pm 0.362$ & $2.12 \pm 0.06$ & $0.31 \pm 0.02$ & $90-125$ & $3.61 \pm 0.13$ & $44.2 \pm 0.8$ & $12.2 \pm 0.5$ \\
\hline $\begin{array}{l}\text { b: Measured wa } \\
\text { c: Concentration } \\
\text { d: All equivalen } \\
\text { e: Calculated wi }\end{array}$ & $\begin{array}{l}\text { ter cont } \\
\text { s of U, } \\
\text { it dose } \\
\text { ith the } \mathrm{c}\end{array}$ & ral as & odel & $\begin{array}{l}\text { ured by ne } \\
\text { rmal distrit } \\
\text { lbraith et a }\end{array}$ & $\begin{array}{l}\text { eutron activa } \\
\text { bution; } \\
\text { al., 2012). }\end{array}$ & tion analys & ysis at the Chin & $\begin{array}{l}\text { chnology; } \\
\text { na institute }\end{array}$ & 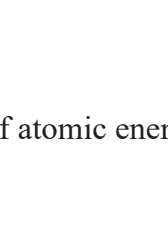 & & \\
\hline
\end{tabular}


TABLE $3 .{ }^{10} \mathrm{Be}$ analytical data at Daqing site

\begin{tabular}{|c|c|c|c|c|c|c|c|c|c|c|c|c|c|}
\hline Samples & $\begin{array}{c}\text { Mass } \\
\text { quartz } \\
\text { (g) }\end{array}$ & $\begin{array}{c}\text { Be } \\
\text { carrier } \\
(\mathrm{mg})\end{array}$ & Latitude & Longitude & Altitude & (cm) & Thickness & $\begin{array}{c}\text { Sample } \\
\text { type } \\
\end{array}$ & $\begin{array}{c}\text { Height above } \\
\text { surface/size } \\
\text { (m) }\end{array}$ & $10 \mathrm{Be} / 9 \mathrm{Be}$ & $\begin{array}{c}\text { 10Be/9Be } \\
\text { error } \\
(\%)\end{array}$ & (atom/g) & $\begin{array}{c}\text { Exposure age } \pm \\
\text { uncertainty } \\
(\mathbf{y r})\end{array}$ \\
\hline \multicolumn{14}{|l|}{ Terrace $\mathrm{T} 1$} \\
\hline HGD14-08 & 30.107 & 0.2461 & 37.259544 & 102.696663 & 3441 & 0 & 2.5 & boulder/granite & $1.2 / 2$ & $1.11247 \mathrm{E}-12$ & 3.1680 & $608254 \pm 19269$ & $13344 \pm 1205$ \\
\hline HGD14-09 & 26.9599 & 0.2699 & 37.259254 & 102.696609 & 3432 & 0 & 2.5 & boulder/granite & $0.5 / 1.3$ & $5.23986 \mathrm{E}-13$ & 3.0904 & $350879 \pm 10843$ & $7705 \pm 693$ \\
\hline HGD14-10 & 25.7075 & 0.241 & 37.259041 & 102.696503 & 3426 & 0 & 2.5 & boulder/gneiss & $1 / 1.5$ & $7.61713 \mathrm{E}-13$ & 3.1744 & $477641 \pm 15162$ & $10529 \pm 951$ \\
\hline HGD14-16 & 30.0079 & 0.2458 & 37.256313 & 102.695001 & 3369 & 0 & 2.5 & boulder/granite & $1.6 / 3.5$ & $3.02524 \mathrm{E}-13$ & 3.1761 & $165752 \pm 5264$ & $3956 \pm 357$ \\
\hline HGD14-22 & 29.8354 & 0.25 & 37.256969 & 102.695702 & 3389 & 0 & 2.5 & boulder/granite & $0.1 / 0.8$ & $6.77539 \mathrm{E}-13$ & 3.1746 & $379748 \pm 12055$ & $8594 \pm 776$ \\
\hline HGD14-23 & 29.972 & 0.2517 & 37.257381 & 102.695984 & 3393 & 0 & 2.5 & boulder/granite & $0.2 / 1.2$ & $8.62754 \mathrm{E}-14$ & 3.5217 & $48462 \pm 1706$ & $1165 \pm 106$ \\
\hline \multicolumn{14}{|l|}{ Terrace T2 } \\
\hline HGD14-18 & 30.0132 & 0.2901 & 37.255253 & 102.694336 & 3351 & 0 & 2.5 & boulder/granite & $0.2 / 0.8$ & $1.11507 \mathrm{E}-12$ & 3.0821 & $720924 \pm 22219$ & $16489 \pm 1486$ \\
\hline HGD14-19 & 24.5073 & 0.2253 & 33.255444 & 102.69445 & 3354 & 0 & 2.5 & boulder/granite & $0.2 / 1.1$ & $1.41835 \mathrm{E}-12$ & 3.4983 & $872173 \pm 30511$ & $21606 \pm 1982$ \\
\hline HGD14-20 & 30.0075 & 0.2495 & \multicolumn{2}{|c|}{$2 \mathrm{~m}$ south of sample 19} & & 0 & 2.5 & boulder/granite & $0.2 / 1.1$ & $2.79689 \mathrm{E}-12$ & 1.9939 & $1555499 \pm 31016$ & $36437 \pm 3185$ \\
\hline HGD14-25 & 30.0081 & 0.2555 & 37.256226 & 102.694389 & 3371 & 0 & 2.5 & boulder/granite & $0.2 / 1$ & $1.37277 \mathrm{E}-12$ & 3.0506 & $781814 \pm 23850$ & $17590 \pm 1584$ \\
\hline HGD14-26 & 25.0845 & 0.2432 & 37.257112 & 102.69458 & 3388 & 0 & 2.5 & boulder/granite & $0.1 / 1.3$ & $1.23744 \mathrm{E}-12$ & 3.0546 & $802483 \pm 24512$ & $17877 \pm 1610$ \\
\hline HGD14-27 & 30.0488 & 0.2546 & 37.257439 & 102.694618 & 3391 & 0 & 2.5 & boulder/granite & $0.5 / 1.5$ & $9.21578 \mathrm{E}-13$ & 3.1078 & $522297 \pm 16232$ & $11788 \pm 1062$ \\
\hline HGD14-28 & 30.0016 & 0.253 & 37.257252 & 102.69455 & 3393 & 0 & 2.5 & boulder/gneiss & $1 / 1.5$ & $1.12670 \mathrm{E}-12$ & 3.1186 & $635531 \pm 19820$ & $14360 \pm 1295$ \\
\hline \multicolumn{14}{|c|}{ Terrace T3 depth profile } \\
\hline HGDT3-01 & 31.4296 & 0.2592 & 37.257061 & 102.693886 & 3389 & 85 & 5 & gravels & $0.02-0.05$ & $1.30104 \mathrm{E}-12$ & 2.4296 & $717695 \pm 17436$ & See model \\
\hline HGDT3-02 & 29.9764 & 0.2484 & 37.257061 & 102.693886 & 3389 & 100 & 5 & gravels & $0.02-0.05$ & $2.05011 \mathrm{E}-12$ & 2.6603 & $1136327 \pm 30229$ & I \\
\hline HGDT3-03 & 25.1784 & 0.2563 & 37.257061 & 102.693886 & 3389 & 115 & 5 & gravels & $0.02-0.05$ & $8.73919 \mathrm{E}-13$ & 3.1803 & $595039 \pm 18923$ & I \\
\hline
\end{tabular}




\begin{tabular}{|c|c|c|c|c|c|c|c|c|c|c|c|c|}
\hline HGDT3-04 & 32.0859 & 0.2514 & 37.257061 & 102.693886 & 3389 & 145 & 5 & gravels & $0.02-0.05$ & $7.71630 \mathrm{E}-13$ & 3.2954 & $404402 \pm 13326$ \\
\hline HGDT3-05 & 30.1135 & 0.2566 & 37.257061 & 102.693886 & 3389 & 175 & 5 & gravels & $0.02-0.05$ & $5.80584 \mathrm{E}-13$ & 3.0688 & $330913 \pm 10154$ \\
\hline HGDT3-06 & 29.3054 & 0.254 & 37.257061 & 102.693886 & 3389 & 205 & 5 & gravels & $0.02-0.05$ & $6.24376 \mathrm{E}-13$ & 3.0946 & $361981 \pm 11201$ \\
\hline HGDT3-08 & 30.041 & 0.2549 & 37.257061 & 102.693886 & 3389 & 285 & 5 & gravels & $0.02-0.05$ & 4.62999E-13 & 3.2264 & $262778 \pm 8478$ \\
\hline
\end{tabular}

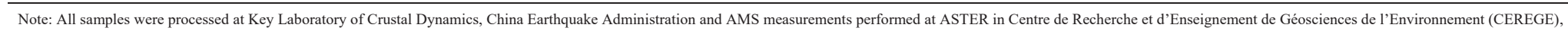

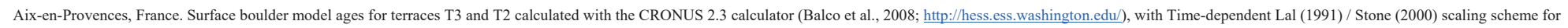
spallation, with density of 2.7 and assuming no erosion and no inheritance. 
TABLE 4. Terrace geometry, vertical terrace offsets and horizontal terrace riser offsets

\begin{tabular}{|c|c|c|c|c|c|}
\hline & Marker & Parameter & $\begin{array}{l}\text { Value } \\
\text { (m) }\end{array}$ & $\begin{array}{l}\text { Error } \\
(\mathrm{m})\end{array}$ & Note \\
\hline \multirow{7}{*}{ Tread widths } & T1 upstream & W1u & 61 & 4 & \\
\hline & $\mathrm{T} 1$ downstream & W11 & 34 & 2 & \\
\hline & T2' upstream & & 42 & 2 & \\
\hline & T2' downstream west & & 9 & 2 & \\
\hline & $\mathrm{T} 2$ ' downstream east & & 22 & 2 & \\
\hline & $\mathrm{T} 2$ tread & $\mathrm{W} 2 \mathrm{u}$ & 135 & 5 & \\
\hline & $\mathrm{T} 2$ tread & W21 & 89 & 3 & \\
\hline \multirow{13}{*}{ Riser heights } & \multirow{2}{*}{$\mathrm{T} 1-\mathrm{T} 0$} & $\mathrm{R} 1 \mathrm{u}$ & 6 & 1 & upstream \\
\hline & & R1d & 2.5 & 0.5 & downstream \\
\hline & \multirow{2}{*}{$\mathrm{T} 2{ }^{\prime}-\mathrm{T} 1$} & & $10-11$ & 1 & upstream \\
\hline & & & $5-6$ & 1 & downstream \\
\hline & T2"-T2' & & 2 & 1 & upstream \\
\hline & \multirow{2}{*}{$\mathrm{T} 2-\mathrm{T} 2$} & & 6 & 1 & upstream \\
\hline & & & $1.5-2.5$ & 0.5 & downstream \\
\hline & \multirow{2}{*}{$\mathrm{T} 2-\mathrm{T} 1$} & $\mathrm{R} 2 \mathrm{u}$ & $16-17$ & 1 & \\
\hline & & $\mathrm{R} 2 \mathrm{~d}$ & 7.5 & 1 & downstream \\
\hline & \multirow{2}{*}{ T3-T2' } & & $16-21$ & 1 & upstream \\
\hline & & & $3.1-4.2$ & 0.5 & downstream \\
\hline & \multirow{2}{*}{$\mathrm{T} 3-\mathrm{T} 2$} & $\mathrm{R} 3 \mathrm{u}$ & $10-15$ & 1 & upstream \\
\hline & & R3d & $1.4-1.7$ & 0.3 & downstream \\
\hline \multirow{8}{*}{$\begin{array}{c}\text { Vertical } \\
\text { terrace offsets }\end{array}$} & T1 A-A' & \multirow{4}{*}{$\mathrm{Sc} 1$} & 1.3 & 0.2 & slop $10^{\circ} / 9.5^{\circ}$ \\
\hline & T1 A1-A1', & & 1.3 & 0.2 & slop $9^{\circ} / 9^{\circ}$ \\
\hline & T2' B1-B1' & & 5.7 & 1 & slop $8.9^{\circ} / 8.5^{\circ}$ \\
\hline & T2’ B-B' & & 6.4 & 1 & slop $10.5^{\circ} / 10.5^{\circ}$ \\
\hline & T2 B1-B1' & $\mathrm{Sc} 2$ & 9 & 1 & slop $9.9^{\circ} / 7.5^{\circ}$ \\
\hline & T2 B-B' & & 10 & 1 & slop $10.5^{\circ} / 9.5^{\circ}$ \\
\hline & T3 C1-C1' & $\operatorname{Sc} 3$ & 19 & 2 & slop $11.7^{\circ} / 7.5^{\circ}$ \\
\hline & T3 C-C' & & 15 & 2 & slop $13.7^{\circ} / 9.5^{\circ}$ \\
\hline \multirow{11}{*}{$\begin{array}{l}\text { Horizontal } \\
\text { riser offsets }\end{array}$} & Stream & Ds & 6.0 & 0.5 & \\
\hline & \multirow{6}{*}{$\mathrm{T} 2 / \mathrm{T} 1$} & $\mathrm{D} 2 \mathrm{t}$ & 35 & 2 & \\
\hline & & $\mathrm{D} 2 \mathrm{~b}$ & 27 & 2 & \\
\hline & & $\mathrm{d} 2 \mathrm{t}$ & 6.5 & 1 & \\
\hline & & $\mathrm{d} 2 \mathrm{~b}$ & 6.5 & 1 & \\
\hline & & D3t & 94 & 3 & \\
\hline & & & 82 & 3 & \\
\hline & \multirow[t]{3}{*}{$\mathrm{T} 3 / \mathrm{T} 2$} & $\mathrm{D} 3 \mathrm{~b}$ & 72 & 3 & \\
\hline & & $\mathrm{d} 3 \mathrm{t}$ & 25 & 2 & \\
\hline & & $\mathrm{d} 3 \mathrm{~b}$ & 28 & 2 & \\
\hline & $\mathrm{T} 2{ }^{\prime}$ & $\mathrm{d} 2^{\prime} \mathrm{b}$ & 29 & 2 & \\
\hline
\end{tabular}


TABLE 5. Summary of slip rates at Daqing site

\begin{tabular}{|c|c|c|c|c|c|}
\hline & $\mathrm{T} 1$ & T2' & T2 & T3 & Average \\
\hline Horizontal offset (m) & $6.5 \pm 1$ & $28.5 \pm 2$ & $35 \pm 2-72 \pm 3 /(54 \pm 19)$ & $>88 \pm 9$ & \\
\hline Vertical offset (m) & $1.3 \pm 0.2$ & $6 \pm 1.5$ & $10 \pm 1$ & $15 \pm 2$ & \\
\hline Ratio (Vertical/ Horizontal) & $0.2 \pm 0.07$ & $0.211 \pm 0.05$ & $0.185 \pm 0.068$ & $<0.170 \pm 0.029$ & $0.191 \pm 0.018$ \\
\hline \multirow[t]{2}{*}{ Age (ka) } & $<1.2 \pm 0.1$ & $5.4 \pm 1$ & $9.3 \pm 0.6-11.8 \pm 1.1$ & $13.7 \pm 1.5$ & \\
\hline & (bound) & (estimated) & (bounds) & & \\
\hline Horizontal slip rate $(\mathrm{mm} / \mathrm{yr})$ & $>5 \pm 0.9$ & $5.5 \pm 1.4$ & $5.7 \pm 2$ & $>6.5 \pm 1$ & $5-8$ \\
\hline Vertical slip rate (mm/yr) & $>1.1 \pm 0.2$ & $1.1 \pm 0.5$ & $1 \pm 0.3$ & $1.1 \pm 0.3$ & $1.1 \pm 0.3$ \\
\hline
\end{tabular}




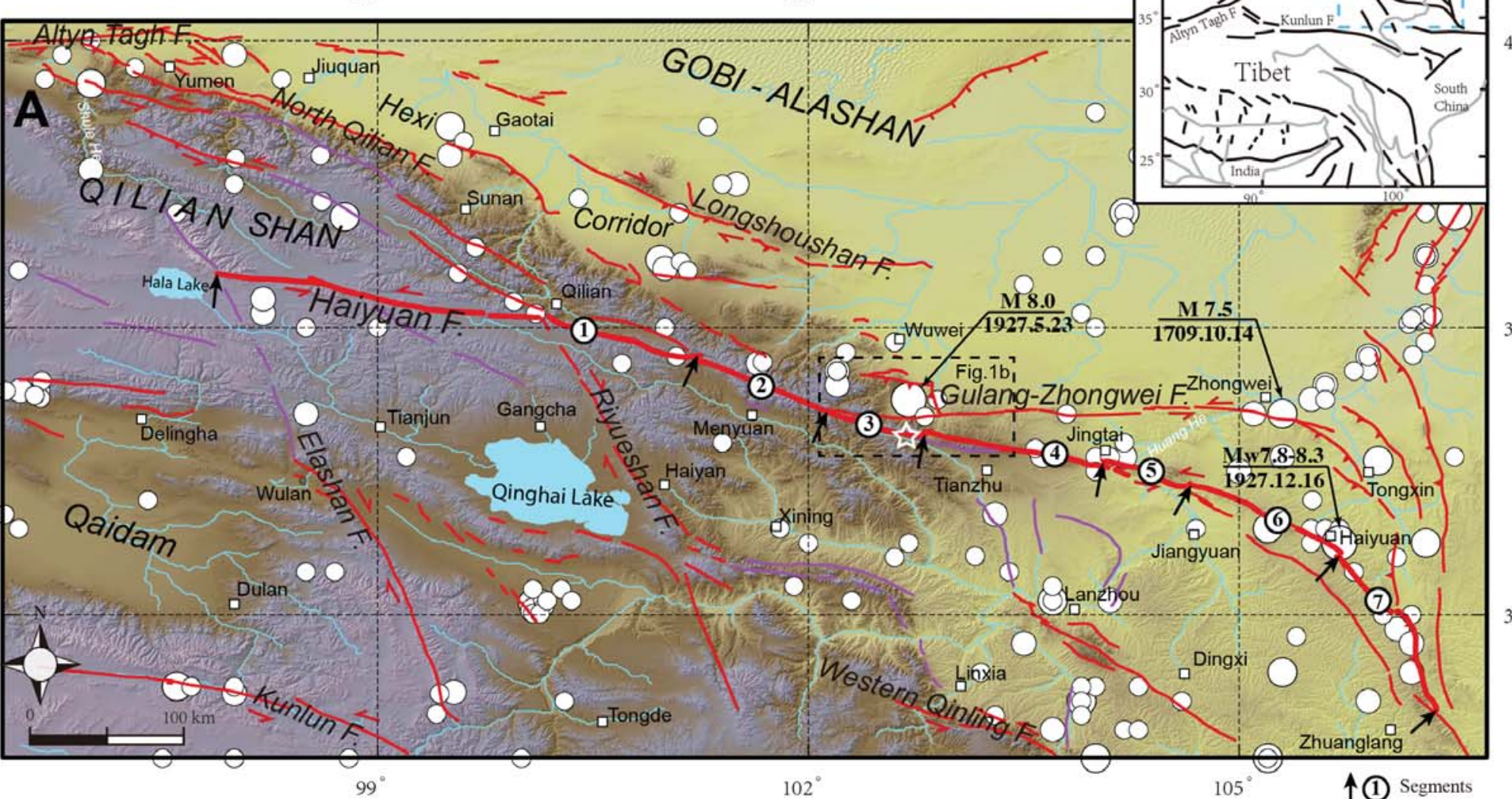

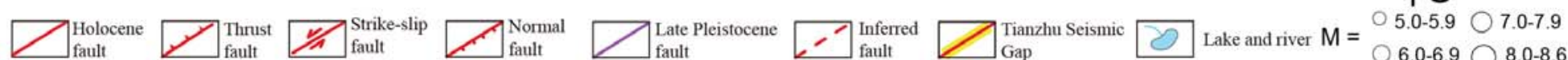
$102^{\circ} 20^{\prime} \quad 102^{\circ} 40^{\prime}$ $103^{\circ} 0^{\prime}$

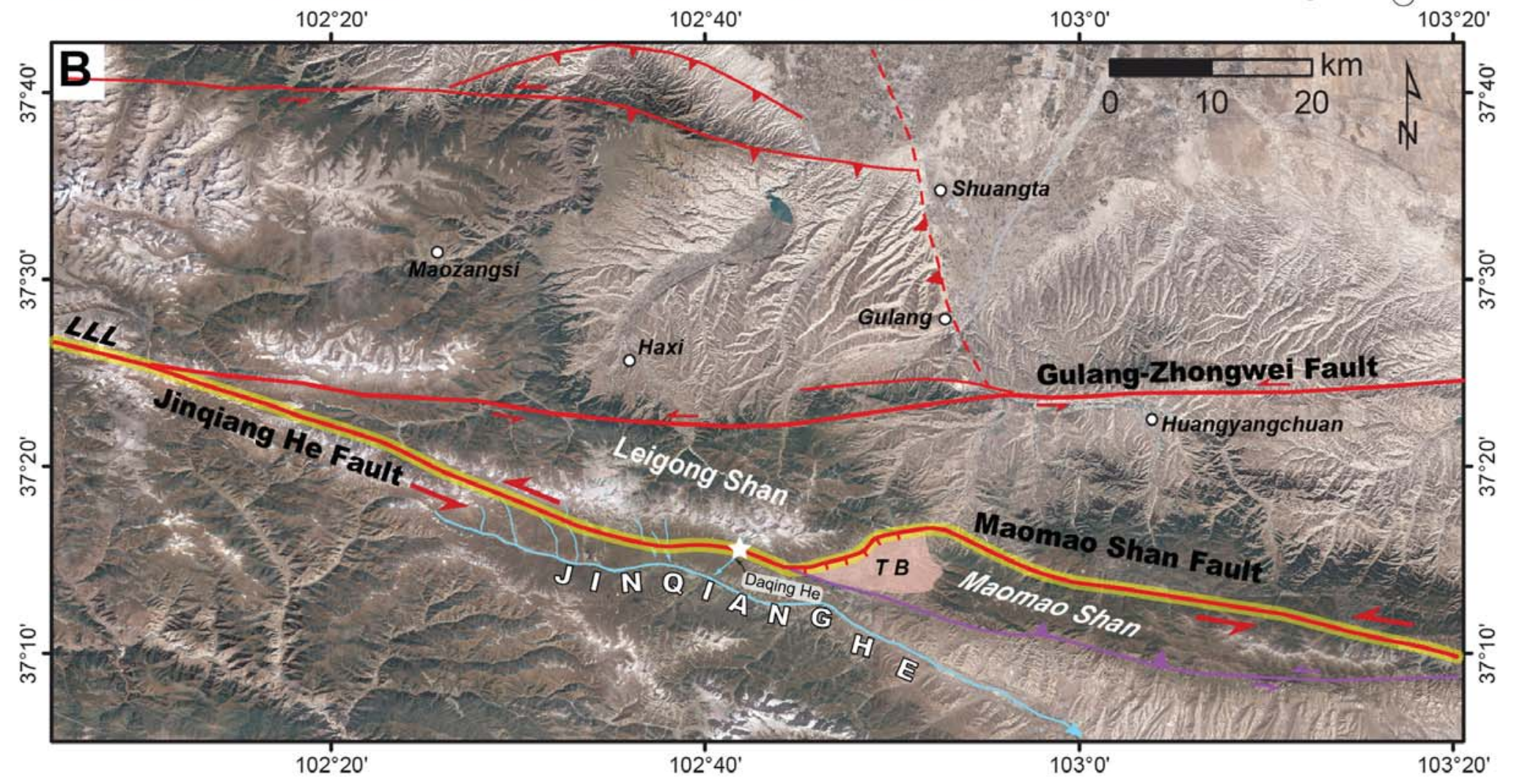




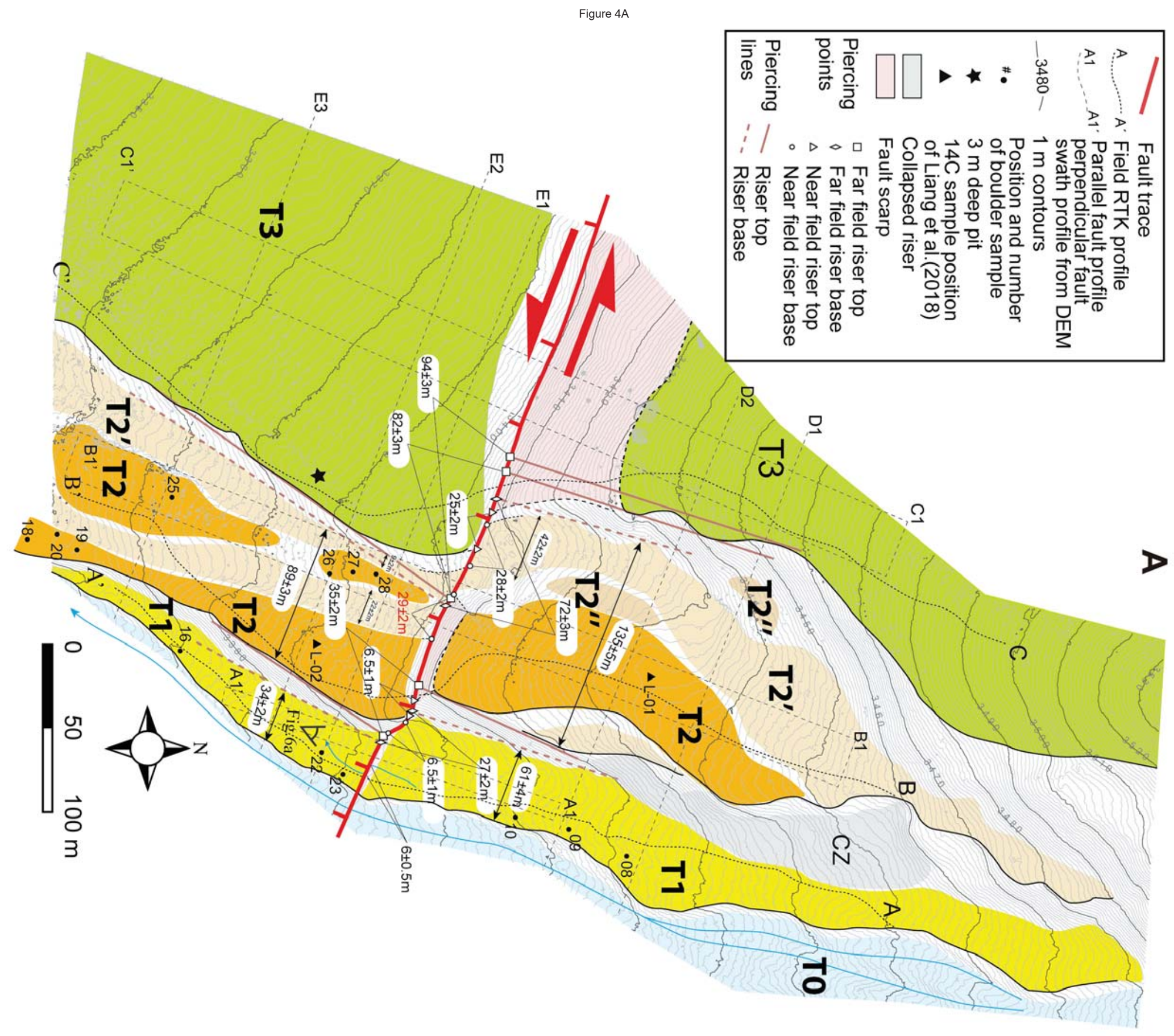



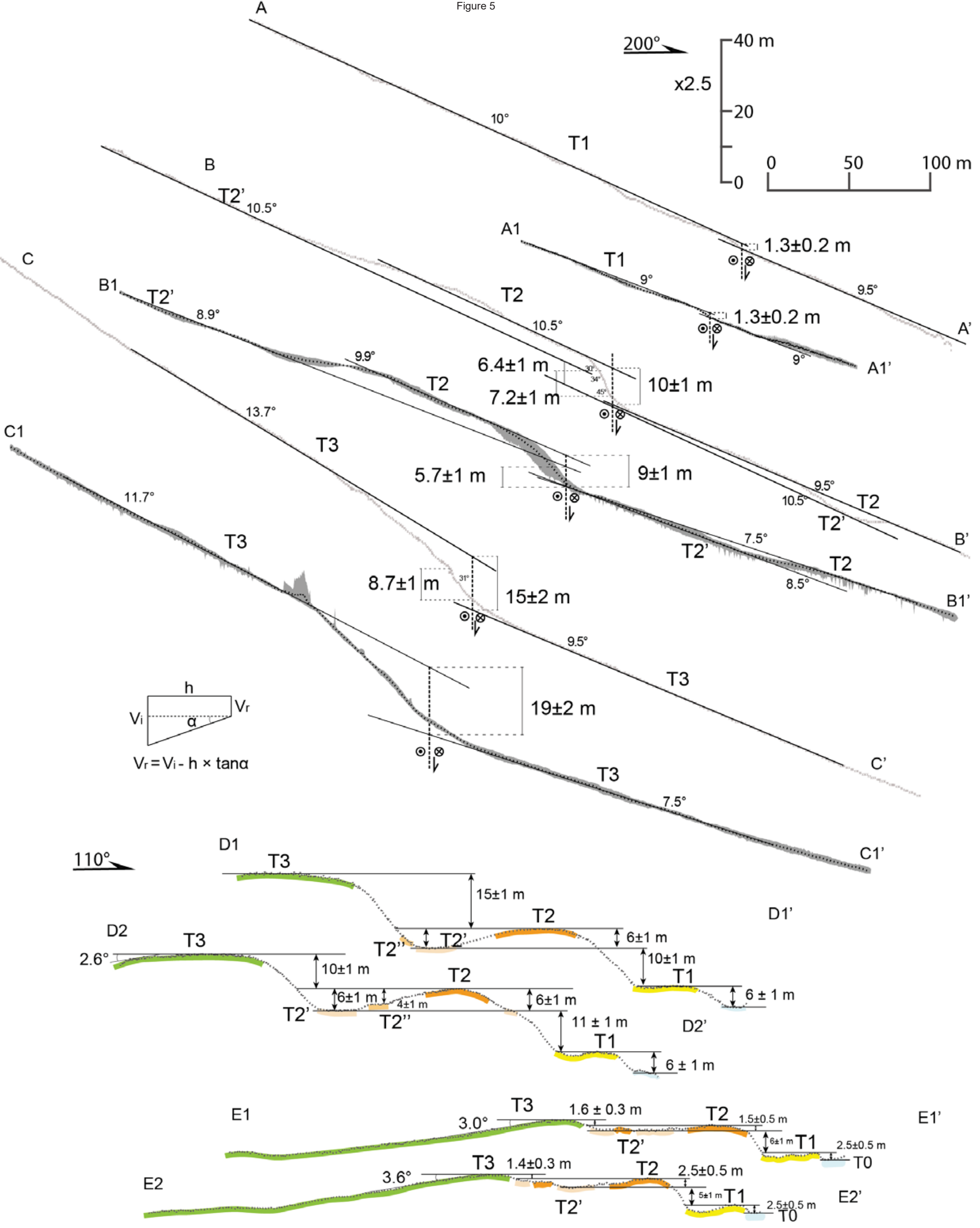

T3 $\begin{aligned} & 1.7 \pm 0.3 \mathrm{~m} \\ & \mathrm{~m}\end{aligned}$

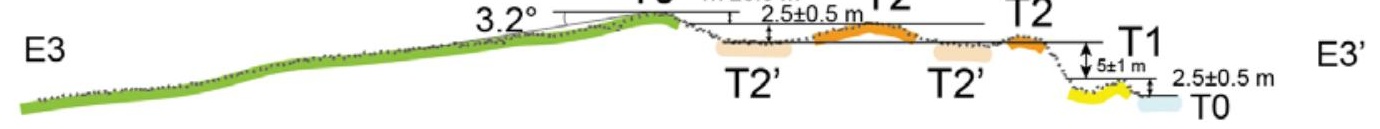



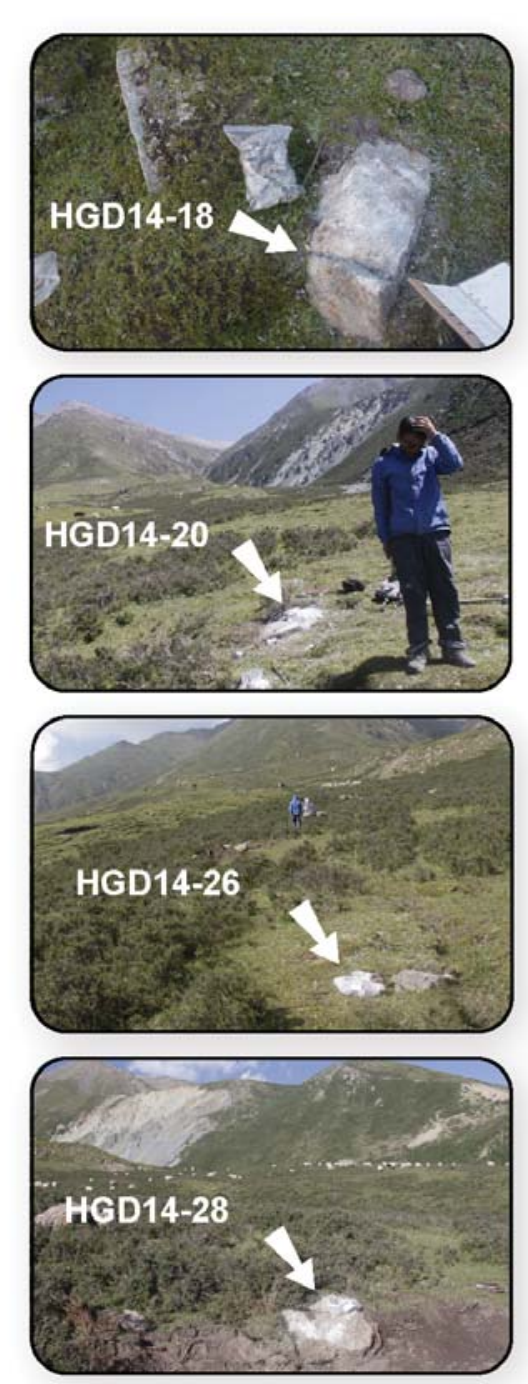
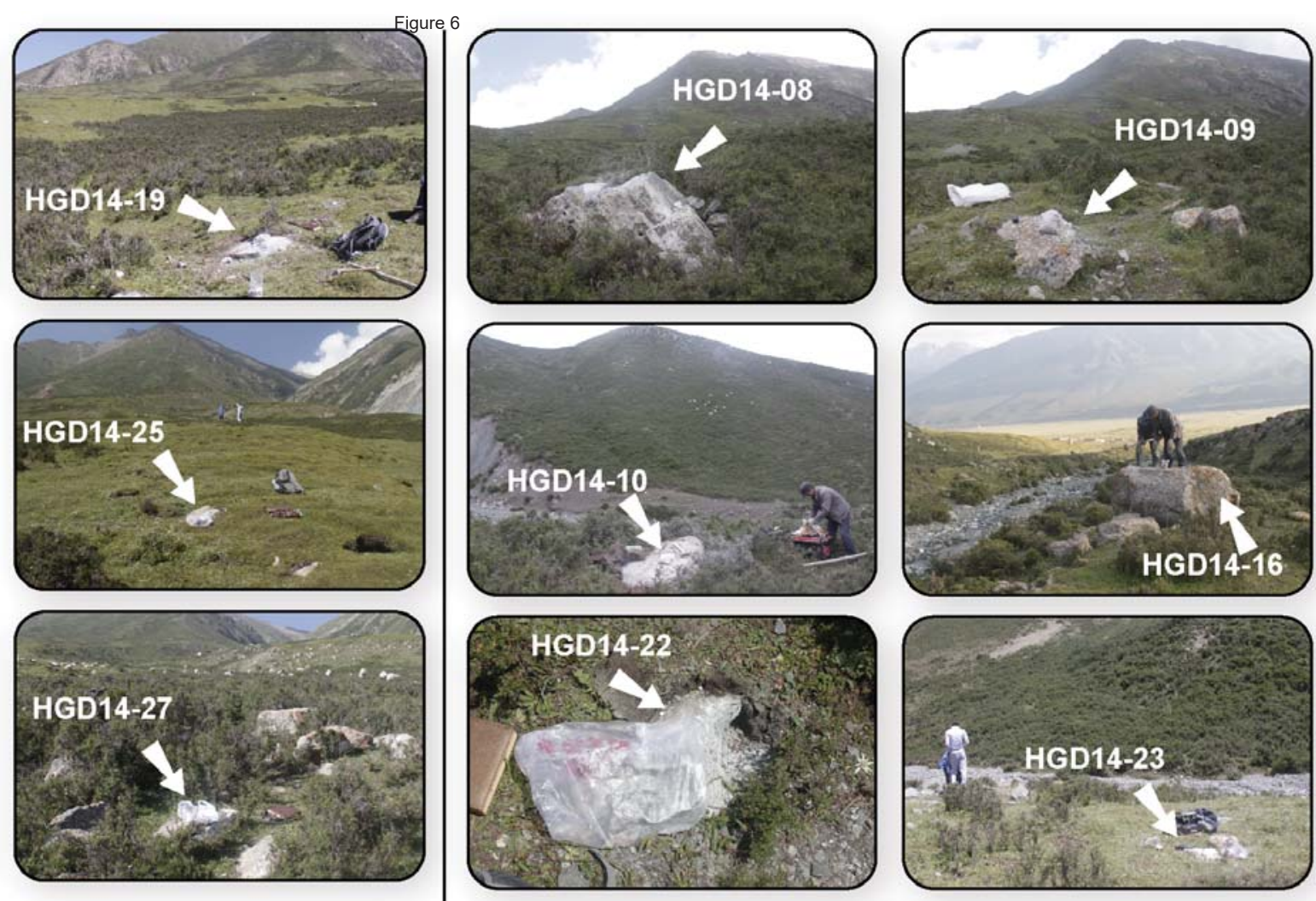

A B 

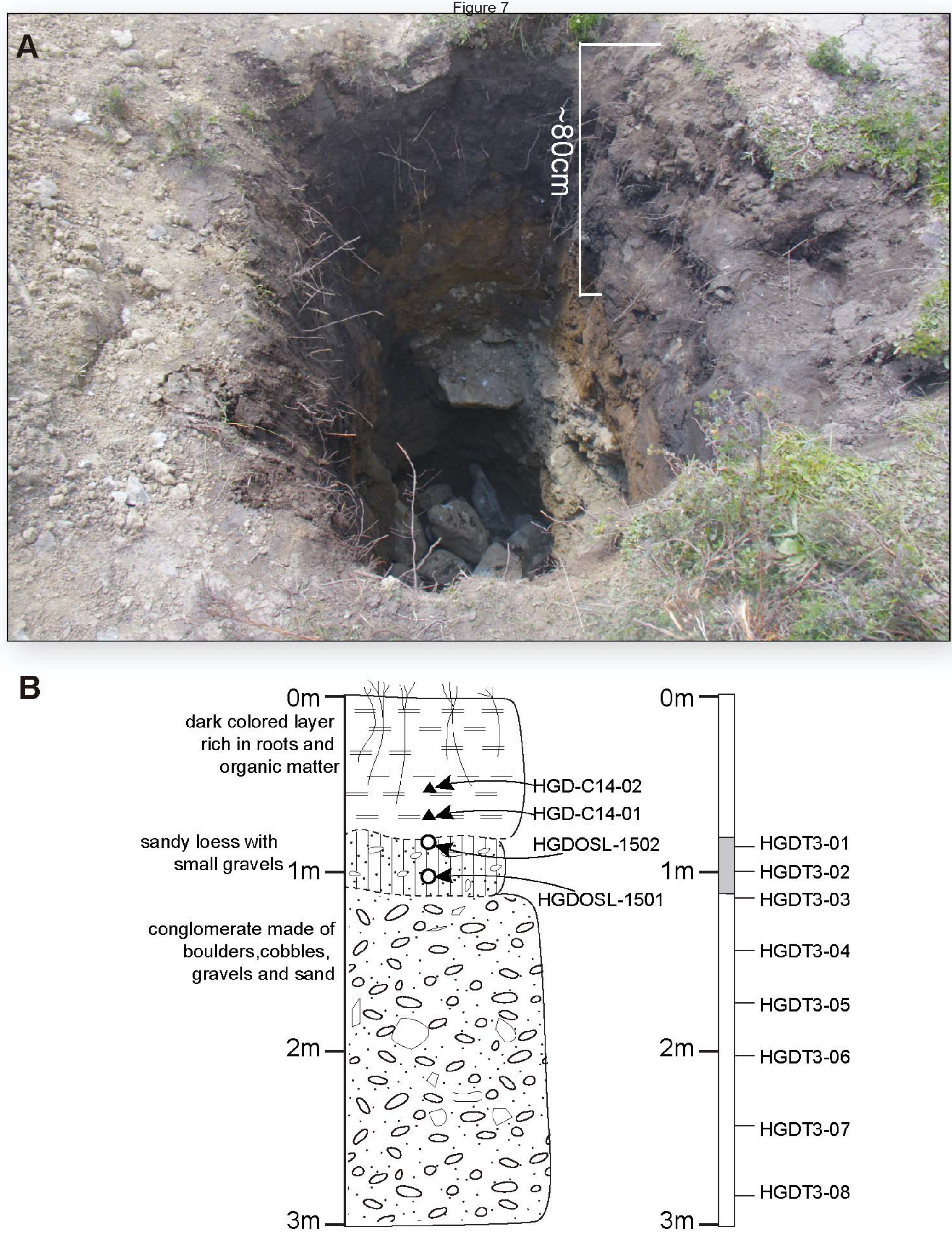

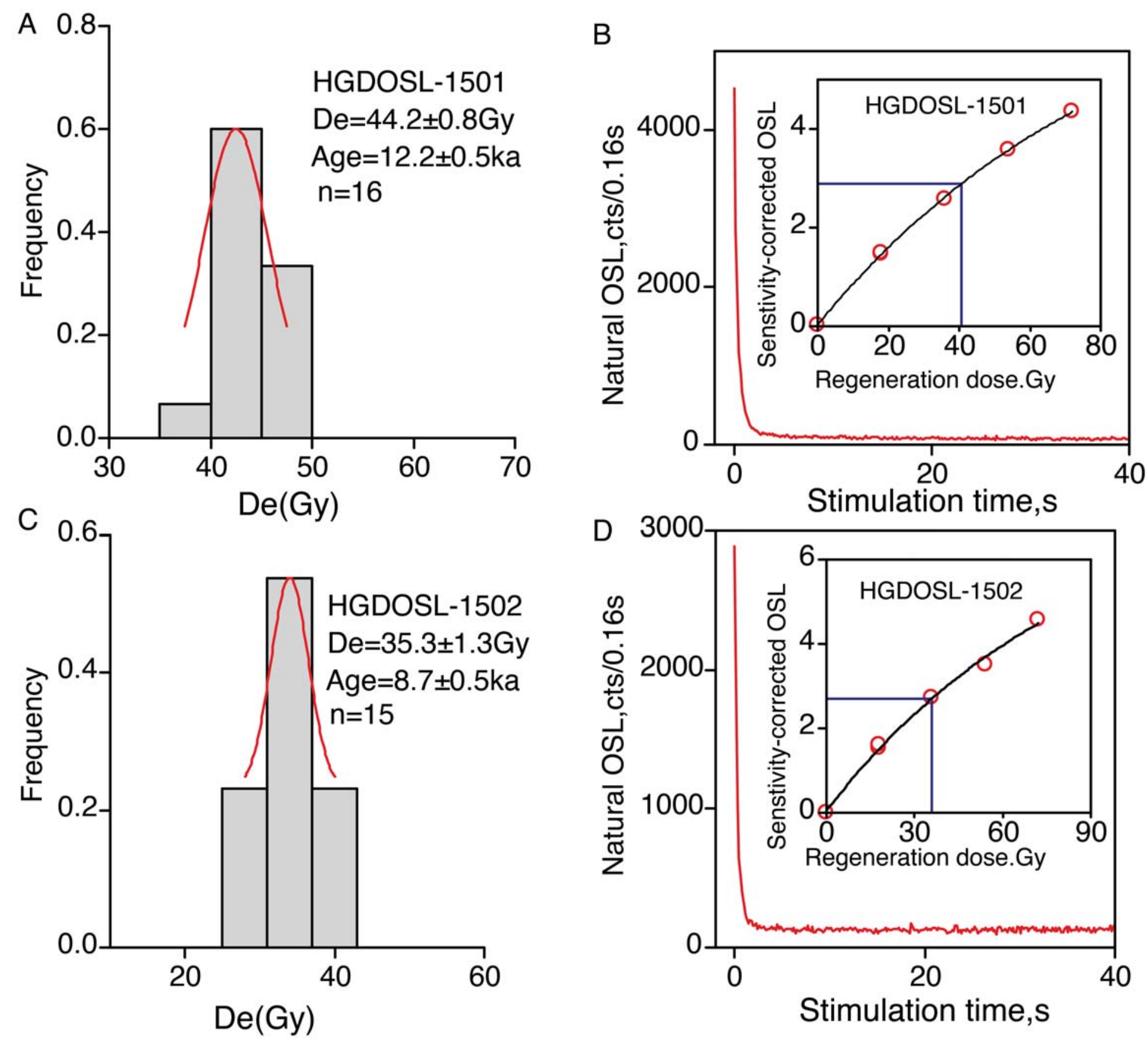


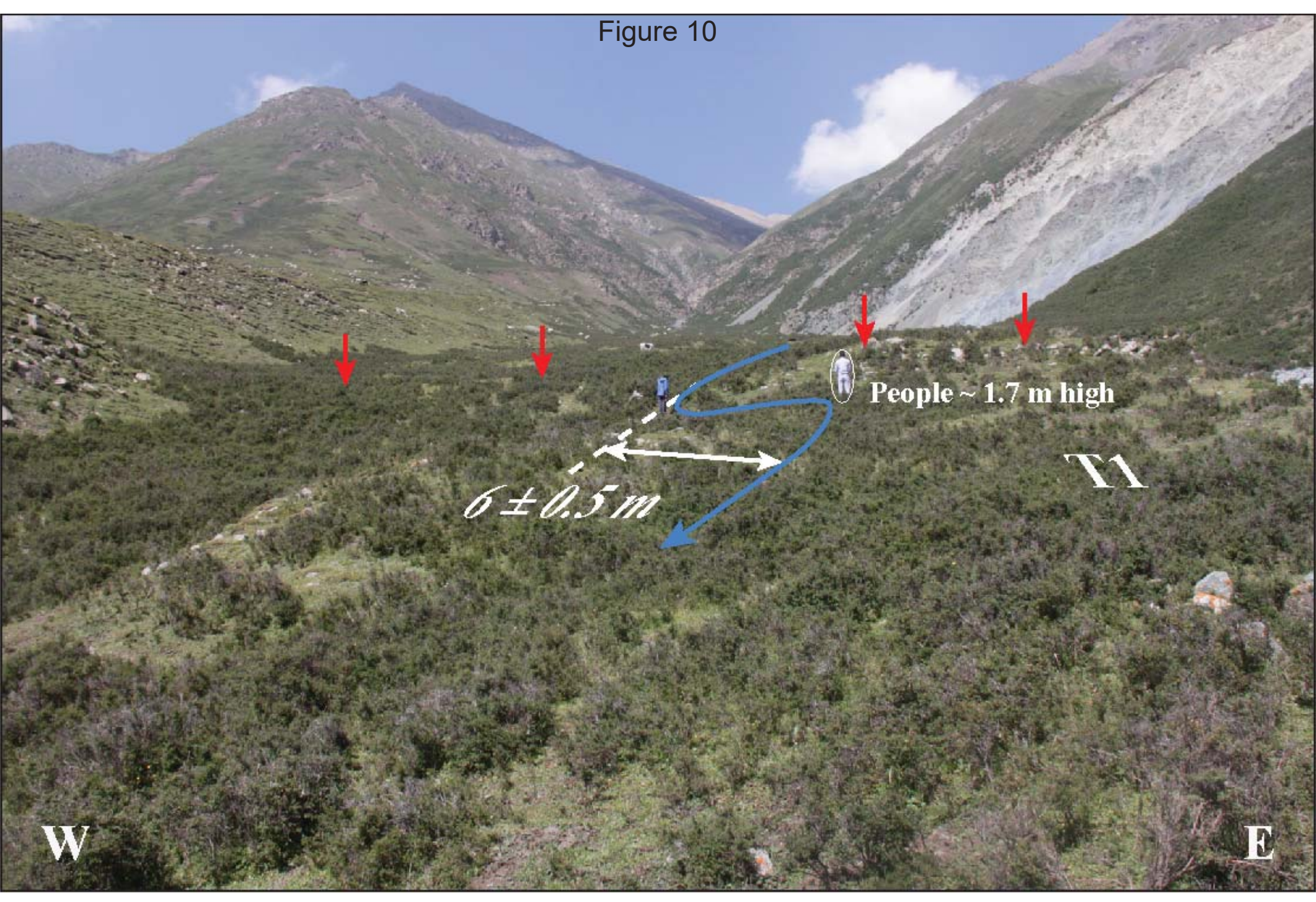




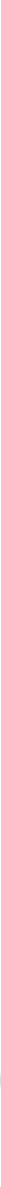


A

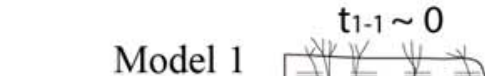

B

$\rho$ : density in $\mathrm{g} / \mathrm{cm}^{3}$

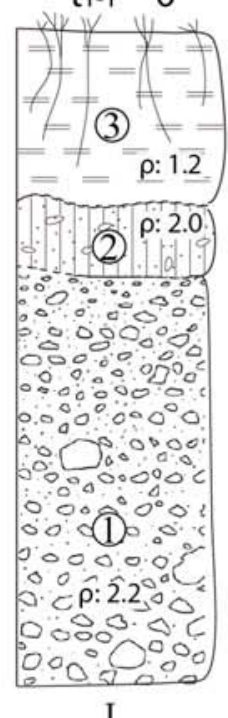

I

Model 2

$\rho$ : density in $\mathrm{g} / \mathrm{cm}^{3}$

$t_{2-1} \sim t_{2-2}$

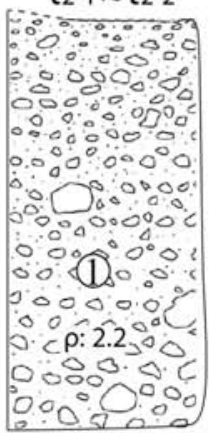

I

II

C

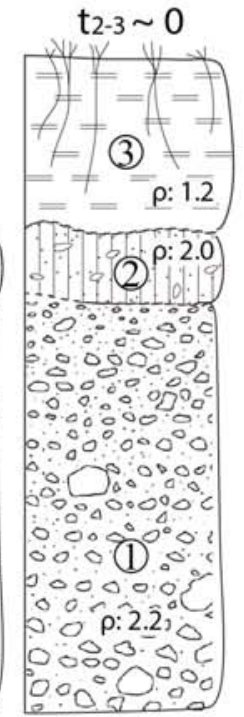

III

$t_{3-2} \sim 0$

Model 3

$\rho$ : density in $\mathrm{g} / \mathrm{cm}^{3}$

$t_{3-2} \sim t_{3-3}$

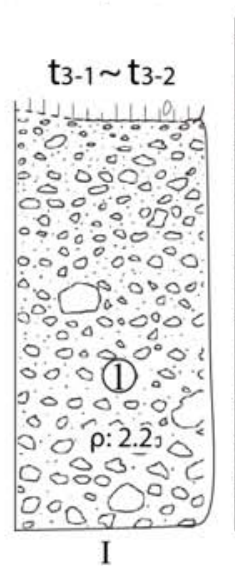

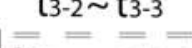
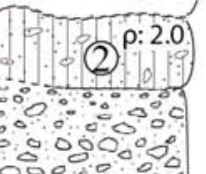

000.000

0.000
0.00000

$\therefore 0.0000$

0.000000

000 (1):

10000.0

$\circ .0 \%: 2.20$

0.000 .06

00000

II
D

${ }^{10} \mathrm{Be}$ Concentration (at/g 105)

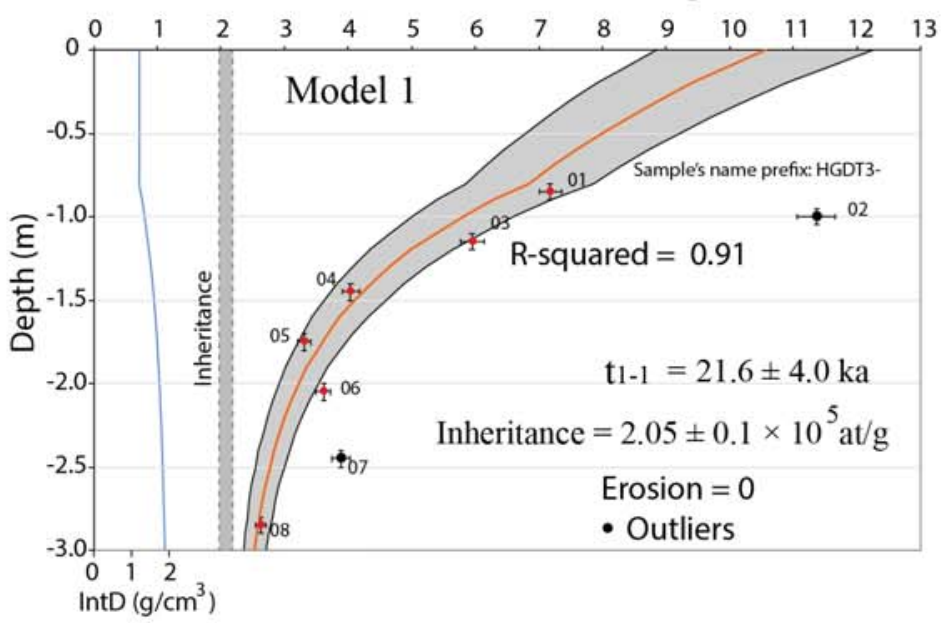

E

${ }^{10} \mathrm{Be}$ Concentration (at/g 105)

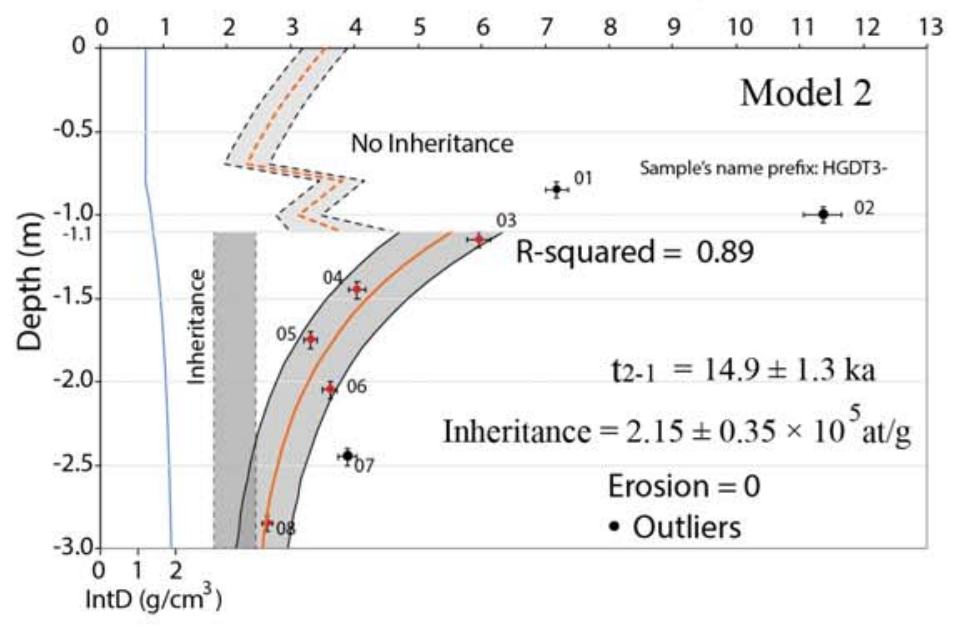

$\mathbf{F}$

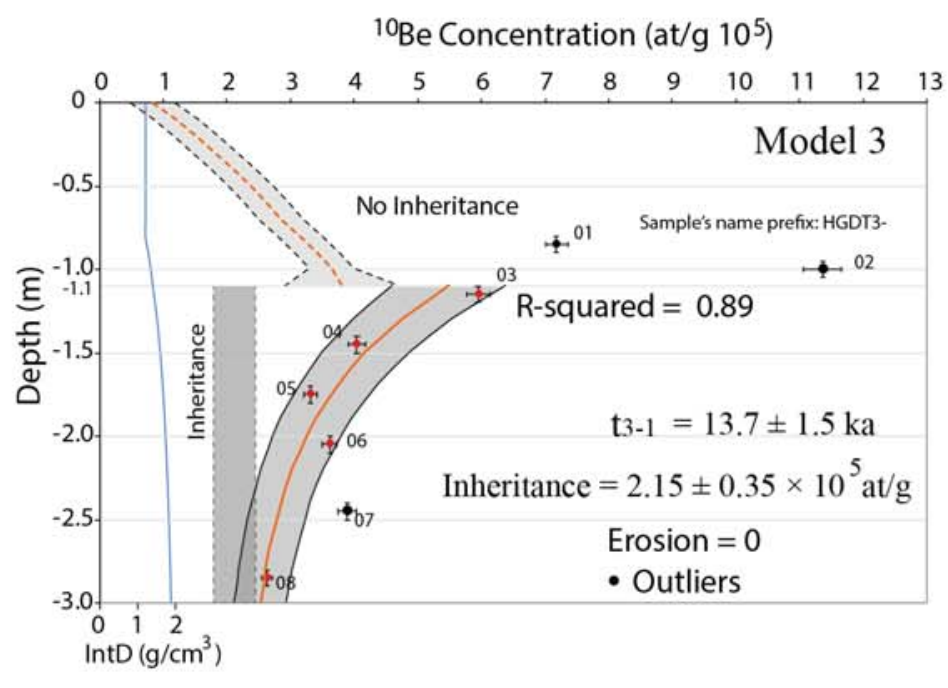

G $\quad 1.5$ Surface samples $10 \mathrm{Be}$ concentration distribution Sample's name prefix: HGD14-

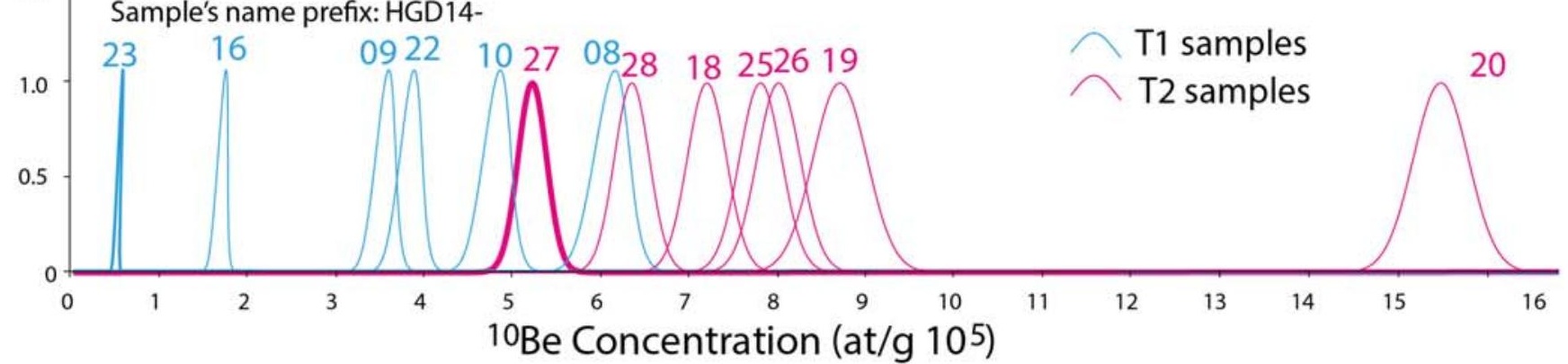




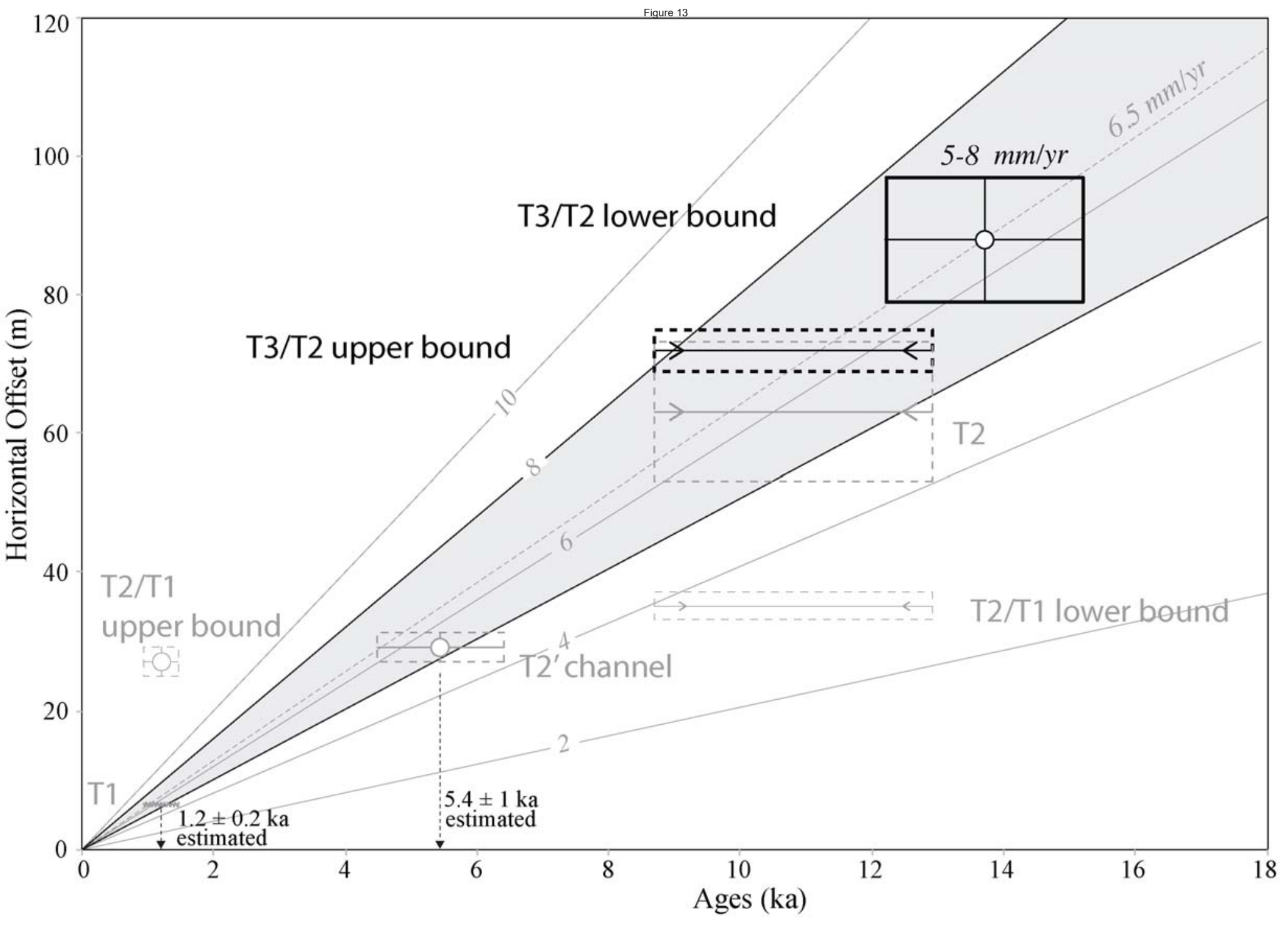

